\title{
Modeling Human Cardiac Arrhythmias: Insights from Zebrafish
}

\author{
Sébastien Gauvrit, Jaclyn Bossaer, Joyce Lee and Michelle M. Collins *
}

Citation: Gauvrit, S.; Bossaer, J.; Lee, J.; Collins, M.M. Modeling Human Cardiac Arrhythmias: Insights from Zebrafish. J. Cardiovasc. Dev. Dis. 2022, 9, 13. https:// doi.org/10.3390/jcdd9010013 Academic Editor: Jau-Nian Chen

Received: 2 December 2021 Accepted: 25 December 2021 Published: 5 January 2022

Publisher's Note: MDPI stays neutral with regard to jurisdictional claims in published maps and institutional affiliations.

Copyright: (C) 2022 by the authors. Licensee MDPI, Basel, Switzerland. This article is an open access article distributed under the terms and conditions of the Creative Commons Attribution (CC BY) license (https:// creativecommons.org/licenses/by/ $4.0 /)$.

\author{
Department of Anatomy, Physiology, and Pharmacology, College of Medicine, University of Saskatchewan, \\ Saskatoon, SK S7N 5E5, Canada; gauvritsebastien@gmail.com (S.G.); jaclyn.bossaer@usask.ca (J.B.); \\ jol299@mail.usask.ca (J.L.) \\ * Correspondence: michelle.collins@usask.ca; Tel.: +1-(306)-966-7100
}

\begin{abstract}
Cardiac arrhythmia, or irregular heart rhythm, is associated with morbidity and mortality and is described as one of the most important future public health challenges. Therefore, developing new models of cardiac arrhythmia is critical for understanding disease mechanisms, determining genetic underpinnings, and developing new therapeutic strategies. In the last few decades, the zebrafish has emerged as an attractive model to reproduce in vivo human cardiac pathologies, including arrhythmias. Here, we highlight the contribution of zebrafish to the field and discuss the available cardiac arrhythmia models. Further, we outline techniques to assess potential heart rhythm defects in larval and adult zebrafish. As genetic tools in zebrafish continue to bloom, this model will be crucial for functional genomics studies and to develop personalized anti-arrhythmic therapies.
\end{abstract}

Keywords: cardiac arrhythmia; heart development; zebrafish; genetic models; atrial fibrillation; inherited arrhythmia; cardiomyopathy; in vivo screening; imaging; cardiac rhythm phenotyping

\section{Introduction}

The healthy human heart beats with a coordinated rhythm. Abnormal heart rhythm, or arrhythmia, refers to conditions in which heart rate or rhythmicity are altered or chaotic. The main inherited cardiac arrhythmias are long QT syndrome (LQTS), short QT syndrome (SQTS), catecholaminergic polymorphic ventricular tachycardia (CPVT), and Brugada syndrome $(\mathrm{BrS})$. These diseases often result from mutations in genes encoding ion channels, leading to altered ionic currents that influence the cardiac action potential [1,2]. The most common cardiac arrhythmia is atrial fibrillation (AF), which is frequently associated with aging, inflammation, or following surgery [3-5]. A portion of AF cases arise in the absence of predisposing factors, often with a younger age of onset and with significant heritability [6]. Arrhythmias also occur in conjunction with inherited cardiomyopathies, including hypertrophic cardiomyopathy (HCM), dilated cardiomyopathy (DCM), arrhythmogenic cardiomyopathy (ACM), and left ventricular non-compaction cardiomyopathy (LVNC). These cardiomyopathies are frequently associated with mutations in genes encoding sarcomeric, desmosomal, or cytoskeletal proteins.

While often considered purely electrical diseases, primary cardiac arrhythmias have variable aetiologies. Genome-wide association studies (GWAS) and whole exome/genome sequencing techniques have implicated diverse pathways in the pathogenesis of cardiac arrhythmia, including developmental [7] and structural genes [8-10]. Many of the loci identified in GWAS are found in non-coding regions, suggesting that these variants alter gene expression which confers disease susceptibility [11,12]. Finding the genes that are affected by variants, and understanding their biological relevance in disease, is critical. The use of in vitro studies [13], animal models, and in silico modeling approaches [14] to investigate pathways implicated in cardiac arrhythmia has started to uncover some of the pathophysiological mechanisms of cardiac arrhythmias.

The zebrafish has emerged as an exceptionally powerful model to study cardiac development and disease. From a practical perspective, zebrafish are optically transparent and 
develop externally, enabling observation during development. They have high fecundity such that large numbers of embryos are easily acquired. Manipulating the zebrafish genome is relatively straightforward, and numerous reporter lines allow for visualization of cellular and organ-level morphology and physiology. Notably, the small size of zebrafish enables them to survive without a functional cardiovascular system early in development, as their oxygen and nutritional needs can be met by diffusion into the embryo. This advantage permits analyses of mutants with little to no cardiac function [15], whereas orthologous mutants in other vertebrate models would not survive long enough to be observed.

Here, we review the major milestones in zebrafish cardiac development, examine the suitability of using zebrafish to study the conduction system, review models of cardiac arrhythmia that have shed insights into the basis of human cardiac arrhythmias, and revisit methodologies to assess cardiac function in zebrafish.

\section{Heart Development in Zebrafish}

Heart development in zebrafish involves several distinct steps. This section will briefly outline the major processes that occur during each stage of heart development (Figure 1).

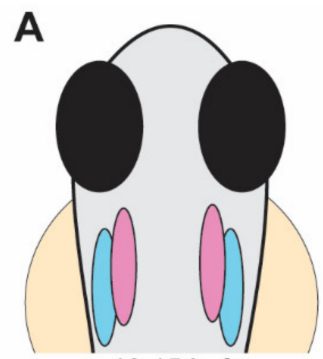

10-15 hpf

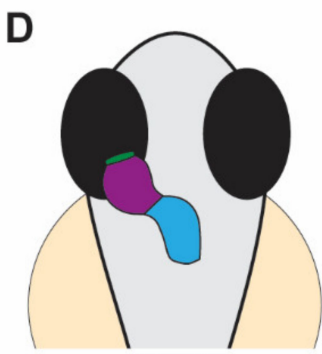

$36 \mathrm{hpf}$
B

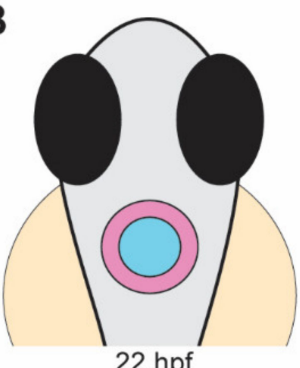

E

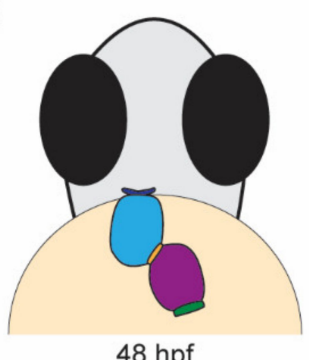

C

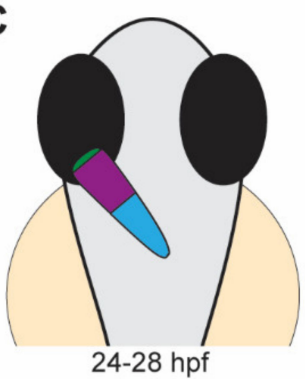

$\mathbf{F}$

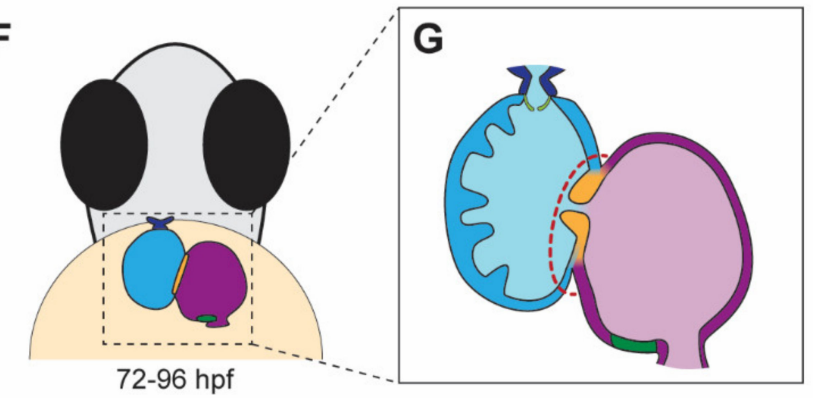

Figure 1. Stages of heart development in zebrafish from 10 to $96 \mathrm{~h}$ post-fertilization (hpf). (A) Atrial and ventricular cardiac progenitors are located in the anterior lateral plate mesoderm by $15 \mathrm{hpf}$. (B) The cardiac disc is visible by $22 \mathrm{hpf}$ as cardiac progenitors surround endocardial cells at the midline. (C) At $24 \mathrm{hpf}$, the linear heart tube forms and jogs to the left in preparation for heart looping. (D) At $36 \mathrm{hpf}$, the heart tube undergoes rightward looping. The AV canal (orange) begins to develop between the cardiac chambers. (E) At $48 \mathrm{hpf}$, the cardiac chambers begin to balloon and expand outwards. The bulbus arteriosus (dark blue) and AV canal (orange) continue to develop and mature. (F) From 72 to $96 \mathrm{hpf}$, the cardiac chambers expand and align beside each other. (G) A cross-section of a $96 \mathrm{hpf}$ heart showing the trabeculae, the finger-like muscular projections on the inner wall of the ventricle, and endocardial leaflets (orange) of the AV canal. (A-D) dorsal views; (E-G) ventral views.

\subsection{Migration and Differentiation of Cardiac Progenitors for the Formation of the Cardiac Disc}

Heart development begins with the specification of myocardial progenitors in the lateral marginal zone at the $40 \%$ epiboly stage ( $~ 5 \mathrm{~h}$ post-fertilization, hpf). Chamber progenitor cells are derived from distinct progenitor pools, with ventricular progenitor cells located more marginally and dorsally compared to atrial myocardial progenitors [16-18]. By early somitogenesis (10-15 hpf, Figure 1A), bilateral pools of atrial and ventricular cardiac progenitors are positioned in the anterior lateral plate mesoderm [18,19]. These bilateral pools 
migrate towards the midline at the 26-somite stage ( $22 \mathrm{hpf}$, Figure 1B), where they fuse to form the cardiac disc with ventricular precursors surrounded by atrial precursors $[17,18,20]$. Differentiation of cardiac progenitor cells can be identified by the expression of chamberspecific genes such as ventricular myosin heavy chain (vmhc) in the ventricular progenitors at around the 13-somite stage ( $15 \mathrm{hpf})$ [17] and atrial myosin heavy chain (amhc) in the atrial progenitors by the 19-somite stage ( 16 hpf) [21].

A network of transcription factors, including GATAs, NKX2.5, and HAND2, controls the differentiation of cardiac progenitors. The role of the Gata transcription factors was highlighted by the discovery of the faust zebrafish mutant carrying a mutation in gata5 [22], which have reduced numbers of cardiac progenitor cells. Progenitors are completely lost in gata5/gata6 morphants, suggesting that Gata factors are complementary for this process [23]. NKX2-5 is required for cardiac development in multiple organisms [24] including human [25]. In zebrafish, two homologs are present, $n k x 2.5$ and $n k x 2.7$. $n k x 2.5$ mutants show increased atrial and decreased ventricular cell numbers while $n k x 2.5 / n k x 2.7$ double mutants display a stronger phenotype demonstrating the synergy between both factors to maintain ventricular identity [26]. Hand2, a basic helix-loop-helix transcription factor regulates the number of myocardial progenitors. Zebrafish hand2 mutants present a substantial reduction in the myocardial cell number [27]. Additional signaling pathways regulate the number of cardiac progenitors, including Bmp [28], Nodal [16,29], Wnt [30], fibroblast growth factors [31,32], and retinoic acid [33,34], highlighting that multiple pathway interactions are needed to provide the necessary number of cardiac progenitors (for more details of the molecular mechanisms, see reviews [35-37]).

\subsection{Heart Jogging and Looping}

The cardiac disc elongates to form a linear tube. At $24 \mathrm{hpf}$, the linear heart tube extends and jogs in an anterior and leftward direction (Figure 1C) [38,39]. This process is necessary for the morphogenesis and robustness of the later process of cardiac looping. If the linear heart tube jogs incorrectly to the right or remains at the midline, the probability of the heart correctly looping afterwards decreases [39]. Heart looping occurs around $36 \mathrm{hpf}$ and corresponds to the rightward bending and twisting of the linear heart tube to create an S-shaped tube with the ventricle positioned to the right of the atrium (Figure 1D). Both intrinsic and extrinsic factors regulate heart looping. A heart cultured in vitro will still undergo heart looping, demonstrating that intrinsic factors play a role in heart looping [40-45]. Blood flow is an example of an extrinsic factor that induces elongation of the ventricular cardiomyocytes in the outer curvature [46]. These cellular shape changes are important for the bending the linear heart tube into an S-shaped tube.

\subsection{Chamber Ballooning}

Correct cardiac function requires chambers to emerge from the linear heart tube. At $48 \mathrm{hpf}$, the atrial and ventricular chambers bulge and expand during a process known as chamber ballooning (Figure 1E). This process is driven by changes in cell shapes within the inner and outer curvatures of the developing chambers, as well as cytoskeletal rearrangements [46,47]. Regionalized cellular elongation in the outer curvatures and compaction in the inner curvatures give the chambers balloon-like shapes. Biomechanical forces, including contractility and blood flow, also contribute to chamber ballooning. Blood flow induces cuboidal cells in the linear heart tube to elongate and expand to form the outer curvatures [46]. Additionally, extracellular matrix (ECM) proteins are crucial during chamber ballooning. Loss of hyaluronan and proteoglycan link protein 1a (Hapln1a), which cross-links hyaluronan with proteoglycans, reduces atrial size and chamber ballooning [48]. Interestingly, the expression of hapln1a is highest in the future atrium and on the left side of the linear heart tube, which is the same region with an expansion of the ECM between the myocardium and endocardium layers before heart looping and chamber ballooning occur. Recent data has shown that crosstalk between the endocardium and myocardium contributes to cardiac morphogenesis, as the expansion of the atrial chamber triggers the pro- 
liferation of the endocardium [49]. This mechanism is mediated by biomechanical signaling that is triggered by increased tensile forces within endocardial cell junctions.

\subsection{Atrioventricular Valve Formation}

Cardiac valves emerge from the atrioventricular canal (AVC), located between the atrium and ventricle (Figure 1F,G). During development, the AVC endocardium is remodeled into mature valves that block retrograde blood flow [50-52]. Endocardial cells first invade the ECM between endocardial and myocardial layers in the AV region and differentiate to give rise to the valve interstitial cells. Subsequent remodeling and leaflet elongation leads to mature valves. Communication between the endocardium and myocardium in the AVC is important for proper valve development. Early specification of valve endocardial cells is mediated by Bmp, Notch, NFAT, and ErbB signaling [52-54]. The ECM plays a critical role in promoting valve formation, acting as an active substrate for cell behaviour via the integrin-mediate focal adhesion complex [50]. While it has been recognized for some time that mechanical forces are required for valve formation, new findings have shed light on how forces are interpreted by the cell. These elegant studies show that regionalized shear stress forces occurring specifically in the AVC region are transformed into bioelectric cues via an ATP-mediated $\mathrm{Ca}^{2+}$ flux and Nfatc1 activation [55].

\subsection{Trabeculation}

Trabeculae are transverse muscular ridges in the inner wall of the ventricle that increase cardiac output and oxygen uptake of the myocardium without increasing heart size $[56,57]$. At the end of heart looping, a subset of cardiomyocytes delaminates from the outer curvature of the ventricular compact layer towards the lumen and form trabeculae (Figure 1F,G) [57-59]. Neuregulin/Erbb2 and Notch pathways cooperate to promote trabecular emergence, as zebrafish lacking $n r g 2 a$ [60] or erbb2 [57] fail to form trabeculae. Mechanistically, the endocardium secretes the ligand Neuregulin which activates its receptor, Erbb2, expressed by the myocardium. Erbb2 signaling also activates glycolysis to rapidly fuel ATP to the cardiomyocytes undergoing cellular shape changes to form the trabecular layer [61]. Loss of Notch signaling also impairs trabeculation [62,63]. Notch signaling is activated in compact layer cardiomyocytes adjacent to the cardiomyocytes that will delaminate to seed the trabecular layer. Blocking Notch signaling increases the number of delaminating cardiomyocytes, suggesting that Notch antagonizes trabecular emergence by lateral inhibition [62]. As described below, ventricular trabeculae are important structures for the fast conduction system in zebrafish.

\subsection{Cardiac Conduction System Development}

The development of the zebrafish cardiac conduction system (CCS) occurs in four stages. A linear conduction path is evident by $24 \mathrm{hpf}$, which travels from the sinus venosus to the ventricular outflow tract [64]. Optical mapping studies revealed that action potentials propagate slowly across the linear heart tube [65]. Unidirectional activation at this early stage suggests that sinoatrial node (SAN) pacemaker activity is already present [64-66]. From 36 to $48 \mathrm{hpf}$, impulse propagation substantially increases, and atrioventricular (AV) conduction delay develops. Optogenetic studies identified that the pacemaker region is confined to the sinoatrial ring [66], and pacemaker cells within this region express the LIM-homeodomain transcription factor Isl1 [67]. In the third stage, from 72 to $96 \mathrm{hpf}$, the ventricle develops an immature fast conduction network as ventricular trabeculation emerges $[64,68]$. The pacemaker region becomes further refined at this stage to the dorsal right quadrant (Figure 1F,G), and AV blocks can be induced through optogenetic manipulation of the AVC region [66]. Moreover, electrical gradient heterogeneity emerges between the inner and outer curvature of the myocardium [65]. Maturation of the fast conduction network is evident by $2-3$ weeks post-fertilization when the ventricular apex has formed [64]. 
The CCS is derived from cardiomyocyte progenitors which give rise to two classes of conduction tissue: slow conducting tissue with longer refractory periods and a fast conducting tissues with rapid impulse propagation [69]. The transcriptional network that drives CCS development is highly conserved across evolution and has been elucidated from mouse models (for a detailed review, please see [70]) (Figure 2). The SAN develops from $T b x 18^{+}, N k x 2-5^{\text {low }}$ progenitor cells. Pitx2, a key player in early cardiac patterning, inhibits the SAN-specific genetic network in the left atrium, which includes the homeobox transcription factor Shox2, LIM homeodomain factor Islet1, and Tbx3 [71-73]. The SAN forms from $N k x 2-5^{-}$precursors, and Nkx2-5 supresses Tbx3 and Hcn4 expression to establish and maintain the boundary between the SAN and atrial myocardium [74]. Shox2 promotes SAN fate by repressing $N k x 2-5$ expression [75] and maintains expression of Islet-1 (Isl1) specifically in the SAN [76-78]. Tbx5 directly regulates the expression of Pitx2. Tbx5 and Pitx2 antagonistically regulate several ion channel genes that are important for cardiac ion currents, including Scn5a, Cx43 (Gja1), and Atp2a2 [79]. The ventricular fast conduction system is patterned by a balance between the transcriptional activator Tbx5, and the repressor Tbx3. Tbx3 expression is enriched in the slow-conducting AVN, whereas $\mathrm{Tbx} 5$ is enriched in the fast ventricular conduction system [80]. Endocardial signaling is required for the development of AV conduction tissue, where Notch and Neuregulin pathways contribute to the formation and induction of slower conducting tissue [69]. Semaphorin signaling acts at various points in cardiovascular development [81] including during epithelial-mesenchymal transition in the outflow tract and AVC regions, cardiac innervation, and myocardial wall morphogenesis [82].

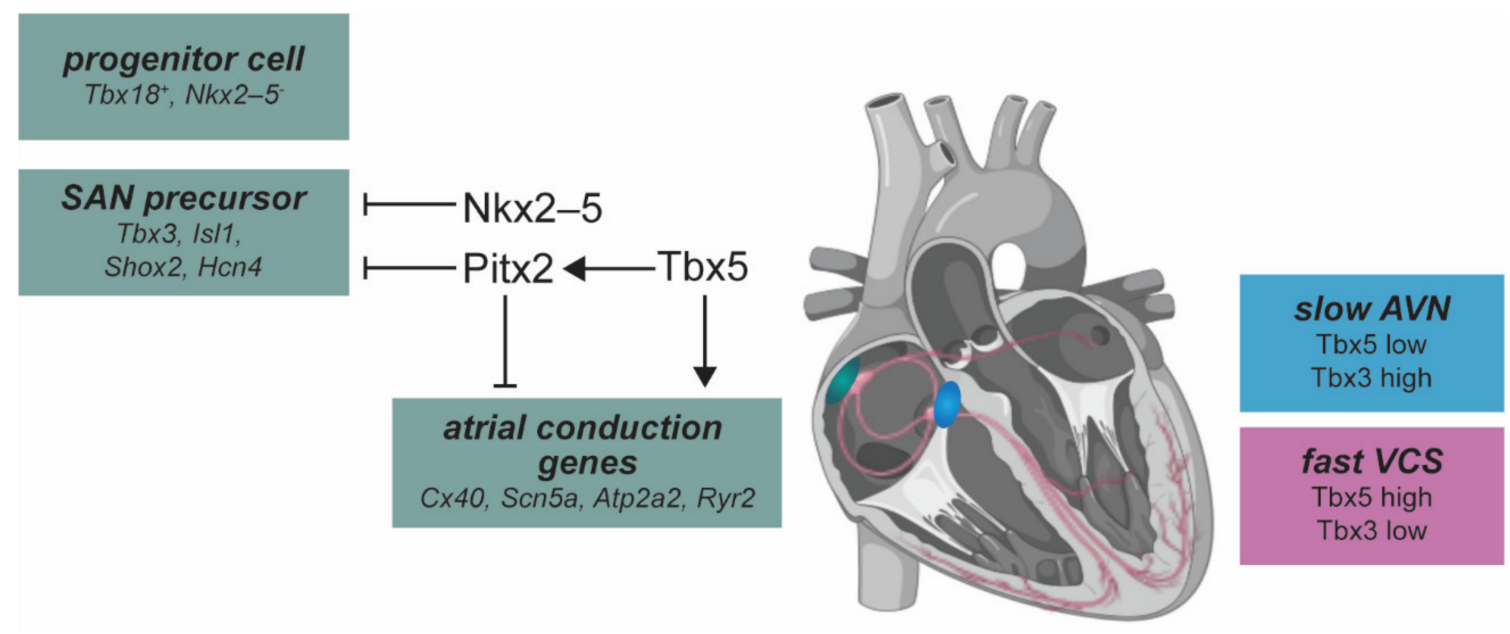

Figure 2. Overview of molecular pathways in the mammalian cardiac conduction system. The sinoatrial node (SAN, green) develops from $T b x 18^{+}, N k x 2-5^{\text {low }}$ progenitor cells. Nkx2-5 represses expression of $T b x 3$ and Isl1 to establish the boundary between the SAN and atrial cardiomyocytes. SAN precursor cell differentiation is marked by expression of Tbx3, Isl1, Shox2, and Hcn4. Pitx2 represses SAN development on the left side of the sinus venosus by repressing this transcriptional network. The Tbx5 (activator) and Pitx2 (repressor) regulatory loop regulates atrial conduction genes. Relative Tbx3/Tbx5 dosage determines specification of the conduction system. The atrioventricular node (AVN, blue) acts as a secondary pacemaker, and is characterized by slow conduction that is patterned by low levels of Tbx5 and high levels of Tbx3. A fast conduction state in the ventricular conduction system (VCS, pink) is specified by higher levels of Tbx 5 and low Tbx3.

\section{The Zebrafish Conduction System}

The CCS is composed of pacemaker cells in the SAN, the atrioventricular node (AVN), and the fast ventricular conduction system. Although the zebrafish heart is formed by only a single atrium and single ventricle, similarities between its CCS with the human CCS supports the use of zebrafish as a model to study CCS development and func- 
tion/dysfunction. Pacemaker cells have been identified in the sinus venosus and atrium junction [67], and slow-conducting AVC cardiomyocytes in the AVN region have been mapped in zebrafish [66]. While the mammalian His-Purkinje system is absent in zebrafish, the ventricular trabecular myocardium has been postulated to serve as a functional equivalent [68].

The molecular profiles of conducting tissues are highly conserved in zebrafish. Tomoseq, a technique to spatially resolve genome-wide transcriptomics data, was used to profile the 2 days post-fertilization ( $\mathrm{dpf}$ ) zebrafish heart. These data identified a sub-compartment that highly expresses pacemaker development genes, including isl1 and shox2 [83]. Recent transcriptome profiling of the sinoatrial ring [84] and AVC cells [85] from the developing zebrafish heart confirms conserved gene expression signatures found in the mammalian SAN and AVN, respectively. Many of the core mammalian SAN/AVN genes are expressed in the developing zebrafish, including tbx18, hcn4, bmp4, cacna1ab in the sinoatrial ring [84], and an abundance of genes encoding connexins, T-type $\mathrm{Ca}^{2+}$ channel (cacna1g), and the pacemaker hyperpolarization channel (hcn4) in the AVN [85].

Cardiac physiology in zebrafish aligns closely with mammalian models. The average resting heart rate of humans is 60-90 beats per minute (bpm), while the average heart rate of zebrafish is 120-180 bpm [86]. This characteristic is a considerable advantage over the widely used rodent models like mouse, which have average heart rates of 300-600 bpm. Adult zebrafish basal electrocardiogram (ECG) characteristics are similar to humans, with a distinct $\mathrm{P}$ wave, QRS complex, and T-wave $[87,88]$. As in humans and large animal models, zebrafish have chamber-specific differences in action potential (AP) shape and duration (for examples, please see [87,89-91]). In atrial and ventricular cardiomyocytes of zebrafish, the resting membrane potential and AP amplitude are comparable with those observed in humans. Like humans, a clear plateau phase is established in ventricular APs, although a fast phase- 1 repolarization is not present. Due to the elevated heart rate in zebrafish, the AP duration in the atrial and ventricular cardiomyocytes is shortened when compared to humans [91].

An estimated $71.4 \%$ of human genes have a minimum of one zebrafish ortholog [92]. The fully mapped zebrafish genome includes orthologs of genes encoding for key cardiac ion channels in the human heart $[93,94]$. Interestingly, some human cardiac ion channels are encoded by non-orthologous genes in zebrafish; for example, the erg genes that encode subunits of the functional $\mathrm{I}_{\mathrm{Kr}}$ channel [95]. Like mammals, zebrafish AP upstroke involves $\mathrm{Na}^{+}$channels, the plateau phase requires L-type $\mathrm{Ca}^{2+}$ channels, and repolarization is driven by $\mathrm{I}_{\mathrm{Kr}}$ channels [91]. Similar fundamental currents are present in zebrafish and human atrial and ventricular cardiomyocytes, yet species-specific differences exist. $\mathrm{I}_{\mathrm{Na}}$ channel composition and density differs between humans and zebrafish cardiomyocytes [96]. Zebrafish cardiomyocytes lack a transient outward potassium current and a slow delayed rectifier potassium current $[91,94,97]$. However, using different cell dissociation techniques, both fast and slow components of the delayed $\mathrm{K}^{+}$currents $\left(\mathrm{I}_{\mathrm{Ks}}\right)$ have been observed in adult zebrafish ventricular cardiomyocytes [98].

There are distinct morphological differences between zebrafish and mammalian cardiomyocytes. Zebrafish ventricular cardiomyocytes are longer $(\sim 100 \mu \mathrm{m})$ and narrower $(\sim 6 \mu \mathrm{m})$ than mammalian cardiomyocytes [91,94,99], more closely resembling neonatal mammals in terms of size. Notably, zebrafish cardiomyocytes lack T-tubules [99] which function in larger mammalian cardiomyocytes to carry extracellular $\mathrm{Ca}^{2+}$ deep into the cell. The extensive network of T-tubules facilitates inward $\mathrm{Ca}^{2+}$ flow through L-type $\mathrm{Ca}^{2+}$ channels and efficient $\mathrm{Ca}^{2+}$ release from the sarcoplasmic reticulum. One explanation for this difference could be the smaller size of zebrafish cardiomyocytes; as the cell membrane and myofilaments are closer, T-tubules may not be required for $\mathrm{Ca}^{2+}$ handling. Significant differences in zebrafish $\mathrm{Ca}^{2+}$ handling have been reported, including a smaller contribution of the sarcoplasmic reticulum to the $\mathrm{Ca}^{2+}$ transient, which may in part result from lower expression levels of ryanodine receptors and reduced sensitivity to cytosolic $\mathrm{Ca}^{2+}$ concentrations [100]. In contrast to mammals, both L-type and T-type $\mathrm{Ca}^{2+}$ channels are expressed 
in both adult zebrafish atrial and ventricular cardiomyocytes [91]. These differences should be acknowledged given the importance of $\mathrm{Ca}^{2+}$ handling and spatial organization of $\mathrm{Ca}^{2+}$ channels [101] to cardiac arrhythmias.

\section{Zebrafish Models of Cardiac Arrhythmia}

Cardiac arrhythmias have multifactorial aetiologies. Several zebrafish models with cardiac rhythm phenotypes have been reported (Table 1). Notably, these models provide unique insight toward disease initiation and mechanisms of pathogenesis. Here, we review the categories of genes implicated in the development and pathogenesis of cardiac arrhythmias and highlight the novel biology that these models reveal.

Table 1. Zebrafish models of cardiac arrhythmia.

\begin{tabular}{|c|c|c|c|c|c|}
\hline Model/Gene & Allele & Cardiac Defect & $\begin{array}{l}\text { Clinical } \\
\text { Arrhythmia }\end{array}$ & Human Ortholog & Ref. \\
\hline atp1a1a.1 & hiphop (tx218) & $\begin{array}{l}\text { 3:1 ratio of atrial contraction to } \\
\text { ventricular contraction, bradycardia, } \\
\text { and AV-block. }\end{array}$ & LQTS & ATP1A1 & {$[102,103]$} \\
\hline cacna1c & $\begin{array}{l}\text { island beat ( } m 379 \text {, } \\
\quad m 458, m 231)\end{array}$ & $\begin{array}{l}\text { Silent ventricle, uncoordinated } \\
\text { contraction of the atrium. }\end{array}$ & $\mathrm{AF}$ & CACNA1C & {$[15,104]$} \\
\hline $\begin{array}{l}\text { cmlc1 } \\
\text { myl4 }\end{array}$ & $\begin{array}{l}\text { s977 } \\
\text { bw } 24\end{array}$ & $\begin{array}{l}\text { Bradycardia, slow conduction in } \\
\text { enlarged atrium, } \\
\text { sarcomere disorganization. }\end{array}$ & $\mathrm{AF}$ & MYL4 & {$[105,106]$} \\
\hline$c x 43$ (gja1b) & Morpholino & $\begin{array}{l}\text { Bradycardia, AV-block, } \\
\text { and fibrillation. }\end{array}$ & $\mathrm{AF}$ & GJA1 & [107] \\
\hline foxn4 & slipjig s644) & $\begin{array}{l}\text { Peristaltic contraction with no } \\
\text { AV delay. }\end{array}$ & & FOXN4 & {$[64,108]$} \\
\hline gja3/cx46 & $\operatorname{dococ}(s 215, \mathrm{~s} 226)$ & $\begin{array}{l}\text { Uncoordinated conduction and } \\
\text { contraction within the ventricle. }\end{array}$ & & CX46 & [109] \\
\hline hon4 & Morpholino & $\begin{array}{l}\text { Bradycardia and prolonged } \\
\text { cardiac pauses. }\end{array}$ & SSS & HCN4 & [110] \\
\hline isl1 (K88X mutant) & $s a 0029$ & $\begin{array}{c}2 \text { dpf: bradycardia due to impaired SA } \\
\text { node function. } \\
\text { 3-4 dpf: sinus block. } \\
\text { 2:1 ratio of atrial to ventricular }\end{array}$ & SSS & ISL1 & {$[67,111]$} \\
\hline kcnh6a (zerg) & breakdance (tb218) & $\begin{array}{l}\text { contraction, bradycardia, reduced } \\
\text { cardiac output, and AV-block due to } \\
\text { impairment of } \mathrm{I}_{\mathrm{Kr}} \text { channel. }\end{array}$ & LQTS & KCNH6 (hERG) & {$[102,112]$} \\
\hline kcnh6a (zerg) & reggae & $\begin{array}{l}\text { Intermittent atrial fibrillation and } \\
\text { acceleration of } \\
\text { cardiomyocyte repolarization. }\end{array}$ & SQTS & KCNH6 (hERG) & [113] \\
\hline kcnma1b & Morpholino & $\begin{array}{l}\text { Decreased contraction of heart } \\
\text { chambers, sinus bradycardia. }\end{array}$ & $\mathrm{AF}$ & KCNMA1 & [114] \\
\hline$m c u$ & $\operatorname{la} 2446$ & $\begin{array}{l}\text { Cardiomyopathy. Thin, dilated atrium, } \\
\text { small ventricle with restricted blood } \\
\text { flow, swollen mitochondria. Heart } \\
\text { rate variability. }\end{array}$ & SSS & $\mathrm{MCU}$ & [115] \\
\hline$n k x 2.5$ & vu176, vu413 & $\begin{array}{c}\text { Reduced heart rate variation, increased } \\
\text { heart rate. }\end{array}$ & $\mathrm{CHD}$ & NKX2-5 & [116] \\
\hline pitx $2 c$ & ups6 & $\begin{array}{c}\text { Embryonic: arrhythmia, sarcomere } \\
\text { disorganization, increased ROS. } \\
\text { Adult: extended P-wave and } \\
\text { PR-interval, fibrosis, } \\
\text { sarcomere disorganization. }\end{array}$ & $\mathrm{AF}$ & PITX2 & [117] \\
\hline$p l n$ & hu10742 & $\begin{array}{l}\text { Adult: structural remodeling, immune } \\
\text { cell infiltration, contractile defects, AP } \\
\text { alternans, altered } \mathrm{Ca}^{2+} \text { handling }\end{array}$ & $\mathrm{ACM}$ & PLN & {$[118,119]$} \\
\hline $\operatorname{scn} 5 a$ & $\begin{array}{l}\text { human } \\
\text { variant }\end{array}$ & $\begin{array}{l}\text { Bradycardia, sinus } \\
\text { pauses, AV-block. }\end{array}$ & LQTS & SCN5A & [120] \\
\hline
\end{tabular}


Table 1. Cont.

\begin{tabular}{|c|c|c|c|c|c|}
\hline Model/Gene & Allele & Cardiac Defect & $\begin{array}{l}\text { Clinical } \\
\text { Arrhythmia }\end{array}$ & Human Ortholog & Ref. \\
\hline $\begin{array}{l}\text { slc8a1a } \\
(\text { ncx } 1)\end{array}$ & $\begin{array}{l}\text { tremblor }(t c 318 d, \text { te } 381 b \\
m 116, m 139, m 158, m 276 \\
m 736)\end{array}$ & $\begin{array}{l}\text { Fibrillation from onset of contraction } \\
\text { (more prominent in the atrium than the } \\
\text { ventricle). Absent circulation. }\end{array}$ & & $\begin{array}{l}\text { SLC8A1 } \\
\text { (NCX1) }\end{array}$ & {$[15,102,121]$} \\
\hline$t b x 5 a$ & heartstrings ( $m 21$ ) & $\begin{array}{l}\text { Slight bradycardia evident during initial } \\
\text { heart tube stage. Heart fails to loop, } \\
\text { contractility declines, and } \\
\text { pericardial edema develops. }\end{array}$ & $\begin{array}{l}\text { Holt-Oram } \\
\text { syndrome }\end{array}$ & TBX5 & [122] \\
\hline$t c f 2$ & hobgoblin (s634) & $\begin{array}{l}\mathrm{AV} \text { block at } 48 \mathrm{hpf} \\
\text { silent ventricle at } 96 \mathrm{hpf}\end{array}$ & & TCF2 & [64] \\
\hline tmem161b & grime (uq4ks) & $\begin{array}{c}\text { Bradycardia, skipped ventricular beats, } \\
\text { increased heart } \\
\text { rate variability }\end{array}$ & LQTS & TMEM161B & [123] \\
\hline \multirow[t]{6}{*}{$\operatorname{ttn} .2$} & $s f c 9$ & $\begin{array}{c}\text { Atrial fibrosis, compromised } \\
\text { sarcomere assembly in atrium and } \\
\text { ventricle, lengthened PR interval. }\end{array}$ & $\mathrm{AF}$ & $T T N$ & [124] \\
\hline & mobitz (s466) & $\begin{array}{c}\text { AV block, sinus pause at } \\
120 \mathrm{hpf} \text {. }\end{array}$ & & & [64] \\
\hline & elektra (s587) & AV block. & & & [64] \\
\hline & daredevil (s275, s563) & AV block, silent ventricle at $120 \mathrm{hpf}$. & & & {$[64]$} \\
\hline & bullseye (s885) & $\begin{array}{l}\text { No heartbeat at } 24 \mathrm{hpf}, \\
\text { AV block at } 36-48 \mathrm{hpf} \text {. }\end{array}$ & & & {$[64]$} \\
\hline & kingpin (s886) & Atrial and ventricular fibrillation & & & [64] \\
\hline
\end{tabular}

\subsection{Ion Channels}

Many inherited cardiac arrhythmias are linked to rare, autosomal dominant variants in genes encoding ion channels or proteins that regulate ion channel function. These are perhaps the best studied and clearly implicated, given the role of ion channel function in shaping the cardiac action potential. The major cardiac channelopathies are long QT syndrome (LQTS), short QT syndrome (SQTS), Brugada syndrome (BrS), and catecholaminergic polymorphic ventricular tachycardia (CPVT).

LQTS is the most common cardiac channelopathy, characterized by an extended QT interval. Loss-of-function mutations in $K C N Q 1$ and $K C N H 2$, and gain-of-function mutations in SCN5A account for $\sim 75 \%$ of affected individuals with LQTS [125]. The breakdance mutant carries a mutation in $k c n h 6 a$ [102]. Homozygous breakdance mutants exhibit a 2:1 atrioventricular block, spontaneous early after depolarizations, and increased action potential duration $[112,126]$. Using a transgenic approach to express the D1275N mutation in SCN5A in zebrafish hearts, Huttner et al. showed that this variant identified in families with conduction defects led to bradycardia, sinus pauses, AV block, and reduced survival [120]. This model was also used to model sick sinus syndrome (SSS) [127]. Acquired LQTS can also be suitably modeled in larval zebrafish, for example, through analyzing cardiotoxic mechanisms (reviewed in [128]). Compounds that block hERG channels act similarly on zERG channels in zebrafish, eliciting bradycardia and 2:1 atrioventricular block [112].

Zebrafish models have also been generated that recapitulate phenotypes observed in SQTS. In humans, gain-of-function variants in KCNQ1, KCNQ1, and KCNJ2 affect repolarizing potassium channels leading to the shortening of the action potential duration (APD) [129]. Zebrafish reggae mutants carry a gain-of-function mutation in the zebrafish ether-à-go-go-related gene zERG, and present cardiac arrhythmia during larval stages. QTc intervals are shortened in both heterozygous and homozygous reggae adult fish [113].

Individuals with CPVT have normal resting ECGs and structurally normal hearts but develop episodic syncope during strenuous exercise or during acute emotion. A limited number of genes have been associated with CPVT. Those identified are linked to $\mathrm{Ca}^{2+}$ handling, and include CASQ2, RYR2, and CALM1-3 [129-131]. While zebrafish orthologs of casq2 [132] and ryr2b [133] are expressed in the zebrafish heart, no models have reported cardiac arrhythmias. Expressing human Calmodulin variants linked to dominantly inherited CPVT did not affect cardiac development or morphology in larval zebrafish. However, $\beta$-adrenergic stimulation induced tachycardia and shorter diastolic phase in these models, demonstrating conserved cardiac effects between human and zebrafish [134]. 
Though $\mathrm{Ca}^{2+}$ handling and excitation-contraction coupling are somewhat divergent in zebrafish, disrupting these pathways in zebrafish phenocopy mammalian models. $\mathrm{Ca}^{2+}$ handling players like the ATP-dependent $\mathrm{Ca}^{2+}$ pump SERCA (zebrafish atp2a1, atp2a2a), NCX1 (slc8a1a), or phospholamban (plna) are conserved in zebrafish. In humans, the phospholamban (PLN) variant p.R14del is found in patients with arrhythmogenic cardiomyopathy. Using a plna p.R14del line developed in zebrafish [119], Kamel et al. showed that embryonic plna p.R14del zebrafish display altered intracellular $\mathrm{Ca}^{2+}$ dynamics related to reduced SR $\mathrm{Ca}^{2+}$ re-uptake [118]. Adult zebrafish phenotypes recapitulate clinical features of patients carrying PLN p.R14del variants, including cardiac remodeling. The authors then showed that istaroxime, a small molecule that stimulates SERCA activity, restores $\mathrm{Ca}^{2+}$ handling defects in the model [118]. This example nicely highlights how "humanized" zebrafish can be exploited in drug discovery settings, which is very powerful given that drug treatments are lacking for patients carrying PLN p.R14del variants.

Zebrafish can be used to assess pathogenicity of putative human variants using different functional assays. Hyperpolarization-activated, cyclic nucleotide-gated cation currents $\left(I_{f}\right.$ or $\left.I_{h}\right)$, or pacemaker currents, are generated by members of the hyperpolarizationactivated cyclic nucleotide-gated (HCN) channel family. Variants in HCN4 have been linked to inherited sinus bradycardia [135], which may be a contributing driver of congenital forms of SSS [136]. Morpholino knockdown of hcn 4 in zebrafish leads to bradycardia and prolonged sinus pauses during embryonic stages, which can be rescued by injecting wild-type hon 4 mRNA [110]. This assay was used to test the functional consequence of variants identified in individuals with congenital SSS and enabled pathogenicity classification for several novel variants of unknown significance [110]. KCNMA1 encodes for the $\alpha$-subunit of the large-conductance $\mathrm{Ca}^{2+}$-activated $\mathrm{K}^{+}$channel, $\mathrm{K}_{\mathrm{Ca}} 1.1$ and has been linked with AF. A knockdown approach on the zebrafish homolog gene, kcnmalb resulted in sinus bradycardia with dilatation and reduced contraction of the atrium and ventricle [114].

Additional conduction mutants identified from large-scale screening efforts have been mapped to genes affecting cardiac electrophysiology. The slow mo (slwm) mutant exhibits bradycardia from the onset of cardiac contraction [137]. While a slow component of $I_{f}$ remains unchanged in slwm mutant cardiomyocytes, the fast kinetic amplitude is greatly reduced. Bradycardia is also observed in the adult slwm mutants but without altered cardiac morphology [138]. The hiphop (hip) mutant carries a missense mutation in the $\mathrm{Na}^{+} / \mathrm{K}^{+}$-ATPase $\alpha 1$-subunit (atp1a1a.1) and has irregular and reduced heart rate [102,103]. The hip mutation acts as a hypomorphic allele leading to prolonged QT interval and refractoriness, indicating that $\mathrm{Na}^{+} / \mathrm{K}^{+}$-ATPase is essential for heart rate regulation by prolonging myocardial repolarization. The zebrafish mutant island beat (isl) [15] was mapped to the voltage-dependent L-type $\mathrm{Ca}^{2+}$ channel $\alpha 1 \mathrm{C}$ subunit (cacna1c) [104]. This mutant exhibits uncoordinated contraction of the atrial cardiomyocytes while the ventricle appears silent. In another forward genetic screen, grime mutants were identified with bradycardia, skipped ventricular beats, and irregular heartbeats without defects in cardiac morphology [123]. This phenotype is caused by a mutation in tmem161b, which encodes a transmembrane domain protein localizing to excitatory cell membranes. Functionally, Tmem $161 \mathrm{~b}$ is required for correct action potential polarization and regulates $\mathrm{I}_{\mathrm{Kr}}$ and $\mathrm{I}_{\mathrm{CaL}}$ currents in cardiomyocytes.

\subsection{Developmental Transcription Factors}

$\mathrm{AF}$ is the most prevalent cardiac arrhythmia and increases markedly with age. AF is highly heritable and linked to both common genetic variants in the general population (i.e., risk alleles) and rare, highly penetrant mutations in familial forms of the disease. From GWAS and exome sequencing studies, transcription factors have emerged as important drivers of disease pathogenesis, including TBX5, GATA4, NKX2-5, PITX2, and ISL1 [7,11,139-141]. Notably, many of these genes are required during cardiac development (Figure 2). 
The SAN transcription factors Shox 2 and Is1l are crucial for the development and maintenance of pacemaker cells in the zebrafish heart [142]. In zebrafish, mutations in isl1 result in sinus arrhythmia development due to loss of pacemaker cells; bradycardia is observed due to prolonged pauses between heartbeats with an irregular rhythm overall $[67,111]$. Mutations in the homeobox gene SHOX2 have been associated with early-onset AF $[143,144]$. Zebrafish with cardiac-specific overexpression of the putative human variants were successfully used to demonstrate the pathological potential of a subset of these novel variants [145]. Similar to morpholino knockdown of shox2 [144], expression of the human variants leads to pericardial edema and reduced heart rate.

Transcription factors involved in early conduction patterning have been studied in zebrafish. Nkx genes function to maintain ventricular identity [26,146]. nkx2.5 mutant embryos have elevated heart rate and decreased heart rate variability compared to wild types, suggesting that Nkx2.5 establishes normal heart rate variation parameters in zebrafish [116]. T-box transcription factor family member Tbx5 is key for proper development of the heart, eye, and pectoral fin buds $[147,148]$. A lethal recessive mutation in heartstrings ( $h s t)$ appears to completely terminate $t b x 5 a$ function, resulting in a lack of pectoral fin development and cardiac dysfunction [122]. hst hearts exhibit severe bradycardia from the onset of contraction and fail to complete the process of heart looping. The heart becomes stretched and thin by $48 \mathrm{hpf}$, and contraction arrests between 72 and $96 \mathrm{hpf}$ [122]. In addition to AF, TBX5 is also implicated in Holt-Oram syndrome, a condition characterized by congenital defects in the upper limbs and the heart, the latter of which often includes cardiac conduction disease and septation defects $[149,150]$.

As identified in several GWAS, variants at the 4q25 locus confer an increased risk for AF [151]. These variants are in an intergenic desert that influences the expression of the nearby gene, PITX2 [152,153]. Loss of pitx2c in zebrafish leads to adult cardiac phenotypes reminiscent of pathologies observed in AF patients, including arrhythmia, atrial conduction defects, sarcomere disassembly, and dysregulated cardiac energetics [117]. In larval zebrafish, sarcomere and metabolic defects are observed prior to the onset of cardiac arrhythmia, and treatment with the antioxidant $N$-acetyl cysteine reduced the severity of cardiac arrhythmia in larval hearts. These data point to an early cardiomyopathy phenotype that may be exacerbated by reactive oxygen species (ROS) levels. As increased oxidative stress is associated with AF in mouse and human [154,155], it may suggest that these factors are important modifiers rather than co-morbidities of disease.

The hobgoblin (hob) zebrafish mutant was found in a genetic screen using a geneticallyencoded $\mathrm{Ca}^{2+}$ biosensor (GCaMP) zebrafish reporter line [64]. hob mutants display an AV block at $48 \mathrm{hpf}$ followed by a silent ventricle at $96 \mathrm{hpf}$ [64]. The hob mutation was mapped to the gene encoding Tcf2, a transcription factor expressed in the AVC and outflow tract of the developing heart. The slipjig (sli) mutant was found in the same screen, exhibiting continuous peristaltic pumping instead of sequential beating of the atrial and ventricular chambers. sli mutants carry a mutation in the gene encoding the transcription factor Foxn4, which is expressed in the AV myocardium [108]. Molecular analysis showed dysregulated expression of AVC markers including tbx2b,bmp4, and versican in sli embryos, suggesting that these are important transcriptional targets of Foxn4 in the heart. Additional zebrafish mutants with cardiac conduction phenotypes such as mobitz, elektra, daredevil, bullseye, and kingpin, found during the same genetic screen [64], were not mapped to specific genes.

\subsection{Cardiac Muscle}

Cardiac structural genes have been associated with arrhythmias like early-onset AF and arrhythmogenic cardiomyopathy, including genes encoding the sarcomere proteins myosin light chain 4 (MYL4) [10,105], titin (TTN) [124], cytoskeletal heart-enriched actinassociated protein CHAP (SYNPO2L) [156], and desmosomal proteins [7,157]. Perturbing the function of these genes in zebrafish leads to atrial cardiomyopathy phenotypes that precede the onset of arrhythmia, highlighting a potential mechanism of arrhythmogenesis. 
Missense variants in MYL4 have been identified in familial early-onset AF cases. A zebrafish model of one identified variant, MYL4 p.Gly11Lys (E11K), tested the pathogenicity of the corresponding mutation E17K in the zebrafish orthologue cmlc1 [105]. E17K adult transgenics exhibited severe bradycardia and slowed atrial conduction with arrhythmia, as well as structural alteration including enlarged atria. Sarcomere disruption was observed at larval stages, evidenced by disorganized myofibrils, abnormal H-zones, and mostly absent Z-discs, while heart rate and cardiac output were unaffected at these stages [105]. Another study, myl4 loss-of-function mutant larvae exhibited prolonged action potential duration, altered $\mathrm{Ca}^{2+}$ handling, and abnormal localization of $\mathrm{Cx} 43$ [106]. The latter finding was also confirmed in atrial biopsies from patients who developed AF following surgery or those with permanent AF. This study also established a significant genetic interaction between MYL4 mutant alleles and common risk alleles at the PITX2 locus [106], which is very interesting given the similar observations in pitx $2 c$ mutant larvae that display disorganized sarcomeres prior to the onset of cardiac arrhythmia [117].

AF GWAS data identifying SYNPO2L also points to a role for structural proteins predisposing the heart to arrhythmogenesis. Morpholino knockdown of chap1 and chap2, the zebrafish orthologues of SYNPO2L, resulted in aberrant heart development, reduced cardiac contractility, and sarcomere defects [158]. No studies on the electrical activity in zebrafish have been reported, but conduction defects were observed in a $\mathrm{CHAPb}$ transgenic mouse model [159]. Defective sarcomere assembly during early development is also evident in a zebrafish mutant carrying an N-terminal truncated titin variant $[124,160]$. Homozygous mutant $t$ tn.2 larval hearts lack Z-discs. Heterozygous $t$ tn. 2 adults present highly disorganized sarcomeres with shortened myofibrils and absent I-bands and M-lines, as well as increased atrial fibrosis and electrophysiological defects. Together, these observations further strengthen the emerging hypothesis that atrial cardiomyopathy predisposes for cardiac arrhythmias like AF.

The desmosome is a specialized cell junction complex that mechanically integrate desmosomal cadherins with the cytoskeleton. Mutations in desmosomal proteins including desmoglein-2, desmocollin-2, plakophilin-2 are linked to arrhythmogenic cardiomyopathy [157]. No genetic mutants have been reported for $p k p 2$ in zebrafish, but morpholino knockdown of $p k p 2$ reduces heart rate and causes additional cardiac development phenotypes [161]. Knockdown of zebrafish orthologs $d s p a$ and $d s p b$ reduces desmosomal junctions, similar to what is reported in ARVC patients [162]. Connexins, or gap junction proteins, are also necessary for correct conduction system patterning in zebrafish. The dococ (dco) mutant, which carries a mutation in Connexin 46 (gja3/cx46), exhibits asynchronous ventricular contraction and AV conduction block [109]. Connexin 43 (cx43) deficient embryos have reduced heart rate, arrhythmia, and develop heart failure [107].

\subsection{Metabolic Regulators}

Cardiac mitochondria control the metabolic processes required for cardiac function, producing over $95 \%$ of the energy in the heart. Oxidative phosphorylation is finely tuned to adapt to the changing metabolic demand of cardiomyocytes. Given the importance of mitochondria for cardiac energetics, it follows that metabolic alterations are reported in cases of cardiac dysfunction, including cardiac arrhythmias like AF and ventricular arrhythmias. However, it is challenging to distinguish between primary drivers of disease and secondary co-morbidities.

Oxidative stress has been implicated as a potential arrhythmogenic mechanism in AF, which has been further explored in zebrafish models. It was reported that AF patients displayed marked upregulation of NADPH oxidase isoform 4 (NOX4) [163]. Interestingly, an embryonic zebrafish NOX4 overexpression model showed significant heart rate variability, which could be attenuated by co-injection with a NOX4 morpholino or with treatment with ROS scavengers, including superoxide dismutase. These data suggest that NOX4 activation and consequent NADPH-driven ROS production is a novel mechanism underlying the development of cardiac arrhythmia [163]. Increased oxidative stress has 
also been suggested as a potential factor in Brugada syndrome (BrS), which is typically considered a channelopathy. Between 20 and $25 \%$ of BrS patients carry variants in SCN5A, leading to a loss of function in the Nav1.5 sodium channel [164]. Additional BrS-related genes encode the $\beta$-subunits of Nav1.5 [165,166]. Recently, a genome-wide CNV study in BrS patients without SCN5A variants identified GSTM3 as a novel genetic modifier in $\mathrm{BrS}$ [167]. GSTM3 encodes a glutathione S-transferase that protects cells from oxidative stress. Adult male GSTM3 heterozygous and homozygous mutant zebrafish have ventricular arrhythmia and pharmacological responses to flecainide and quinidine comparable to BrS ECG parameters [167], providing further evidence that increased oxidative stress can lead to cardiac arrhythmia. In zebrafish, loss of the mitochondrial $\mathrm{Ca}^{2+}$ uniporter $\mathrm{MCU}$ leads to changes in adult atrial morphology, including sarcomere disassembly, as well as conduction defects [115]. Loss of MCU attenuates mitochondrial $\mathrm{Ca}^{2+}$ uptake, leading to high levels of ROS, which could be indicative of pathological remodelling.

The question of whether oxidative stress is an arrhythmogenic mechanism that may be modulated pharmacologically has also been explored in zebrafish. In our studies of pitx $2 c$ mutant larvae, transcriptomics data indicated aberrant gene expression in oxidative phosphorylation pathways prior to when cardiac arrhythmia was observed [117]. In line with this, pit $x 2 c$ mutants had increased ROS levels, and antioxidant treatment could diminish the arrhythmic burden. The efficacy of mitochondrial $\mathrm{Ca}^{2+}$ uptake enhancers to restore cardiac rhythm was also recently reported [168]. In a screen using the tremblor mutant, a model for $\mathrm{Ca}^{2+}$ induced cardiac arrhythmia [121], ezetimibe and disulfiram, drugs that stimulate SRmitochondria $\mathrm{Ca}^{2+}$ transfer, were shown to rescue cardiac arrhythmia [168]. Most common anti-arrhythmic compounds target ion channels, consequently leading to proarrhythmic side effects. Exploring molecules that act on other arrhythmogenic substrates could lead to developing promising new candidates to explore.

\section{Techniques for Assessing Cardiac Rhythm and Function in Embryonic and} Adult Zebrafish

\subsection{Tools to Study Cardiac Rhythm at Embryonic Stages}

Due to its amenability to live imaging and genetic manipulation, the zebrafish model provides a great opportunity for understanding the genetic and molecular mechanisms underlying cardiac arrhythmia. Here we summarize the different techniques used to assess, image, and control the rhythmicity of heart contractions in zebrafish embryos and adults.

The zebrafish embryo is easy to image due to its transparency, and light microscopy is suitable to detect early arrhythmia. High-speed acquisition of the beating heart is key to the identification of arrhythmia. One of these techniques, spinning disk microscopy, provides many attractive advantages for imaging heart contractions in vivo during development due to its speed with higher frame rates. The high speed allows the imaging of multiple samples in a short amount of time, making it an excellent instrument for high-throughput chemical screening assay in zebrafish embryos [169]. After acquiring heartbeat movies, a kymograph, a plot representing spatial position over time, can be generated to quantify heart rate, heart rate variability, and cardiac output in larvae $[67,117,123,170]$. Automation of this process using algorithms that have been developed to quantify heart rate variability like ZebraBeat [171], MUSCLEMOTION [172], and ImageJ/FIJI-based tools [86,173] to analyze video data can improve operator outcomes in terms of speed.

Light-sheet microscopy is another fluorescence microscopy technique suitable to detect arrhythmia. It uses a plane of light to optically section and views tissues at a cellular resolution. Light-sheet microscopy presents the advantage of deep imaging with a thin plane of light, limiting phototoxicity and photobleaching [174]. By combining this approach with optogenetics, a technique in which channels can be controlled with light, Arrenberg et al. created an optically controlled pacemaker by expressing halorhodopsin and channelrhodopsin in zebrafish cardiomyocytes [66]. Using these tools, the cardiac pacemaker was mapped using a patterned illumination to localize the areas sensitive to hyperpolarization at the inflow tract and AV canal during early development. By vary- 
ing the light intensity, the authors manipulated cardiac rhythm to simulate tachycardia, bradycardia, atrioventricular blocks, and cardiac arrest [66].

One obvious challenge while imaging cardiac rhythm is the constant motion of the heart. Different solutions are possible to overcome the limitation for long time-lapse in larvae, such as preventing heartbeat by injecting a morpholino targeting the cardiac troponin T gene tnnt $2 a$ [175]. The heart may be transiently stopped for imaging using tricaine, an anesthetic drug that prevents sodium ions from entering the cell and thus eliminates the action potential, or blebbistatin, which uncouples excitation-contraction by inhibiting myosin ATPase activity. However, these approaches are limited due to their effect on heart development and physiology. One exciting possibility is the development of algorithms that synchronize and acquire the entire beating heart to perform 3D reconstruction devoid of motion artifacts [176].

By taking advantage of the permeability of the zebrafish embryo, chemical dyes can be used to image heartbeats by indicating electrical potential changes using di-8-ANEPPS or $\mathrm{Ca}^{2+}$ dynamics such as Fura-2 [65]. They present the advantages of being relatively easy to use, although cell specificity and poor suitability for chronic imaging are drawbacks. Biosensors, or genetically encoded reporters, have been developed for use in zebrafish due to their reduced toxicity and ability to target specific cell types. Such biosensors can be used to visualize signaling pathways essential for cardiac rhythm, including $\mathrm{Ca}^{2+}$ dynamics using GCaMPs, a synthetic fusion of green fluorescent protein (GFP) and calmodulin as the sensing element $[64,177]$. Recently, fluorescence resonance energy transfer (FRET)-based $\mathrm{Ca}^{2+}$ indicators based on troponin $\mathrm{C}$ variants, Twitch proteins, were tested transiently in zebrafish and showed promising results as new genetically encoded $\mathrm{Ca}^{2+}$ indicators [178]. These new biosensors have been described as having potentially less interference with $\mathrm{Ca}^{2+}$ regulatory elements than the calmodulin-based biosensors. It would be interesting to generate stable transgenic lines from these genetic constructs to test them for cardiac arrhythmias. Another recently developed direction used bioluminescence as an approach to detect arrhythmia by fusing GFP with aequorin [179]. This tool is especially well suited to prolonged imaging without artificially stopping the heart.

Genetically encoded voltage reporters have been developed and tested in zebrafish. One of the first zebrafish applications used a FRET strategy called Mermaid [180,181]. Mermaid is derived from a tunicate voltage-sensitive phosphatase in which the change in voltage triggers conformational changes in the voltage-sensing domain. The Mermaid construct was able to report the voltage dynamics of a beating heart even though it could not define the action potential waveform. Moreover, its FRET spectra excluded its use in combination with a GCaMP sensor. To overcome this limitation, a mutated Archaerhodopsin protein with a far-red spectrum was used as a voltage indicator in combination with a GCaMP sensor [182]. This construct, named CaViar, allows for simultaneous mapping of membrane voltage and $\mathrm{Ca}^{2+}$ dynamics in the heart and the measurement of the cardiac action potential. Recently, a voltage-sensitive fluorescent protein sandwiched between a FRET pair of proteins (VSFP-butterfly) was used to characterize cardiac arrhythmia phenotypes in the tmem161b mutant [123]. In addition to imaging-based approaches, cardiac ion channel behavior may be recorded from larval hearts $[85,137,183]$ or dissociated adult cardiomyocytes $[123,184]$ using patch-clamp techniques.

\subsection{Applications for Adult Cardiac Rhythm Phenotyping}

Cardiac rhythm can be monitored in adult zebrafish even though it presents more challenges due to the opacity of the animal. Echocardiography is an ultrasound imaging method that uses a high-frequency transducer directly applied to the body of the anesthetized zebrafish. This technique is non-invasive and enables quantification of cardiac output parameters including chamber area, fractional area change, and fractional shortening using brightness mode (B-mode) [117]. Pulsed-wave Doppler imaging provides information on blood flow and valve function $[53,185]$. ECG is the most common method to evaluate cardiac electrophysiology clinically and may be applied in zebrafish. Elec- 
trodes are placed on top of the cardiac region to record the $\mathrm{T}$ wave, $\mathrm{P}$ wave, and QRS complex. The measurement of the $\mathrm{P}$ wave duration and PR intervals, representing atrial depolarization, can indicate atrial conduction defects, as has been reported for several models $[87,117,124]$. Recently, simultaneous bipolar dual-lead ECG recordings that more closely mimic the clinical situation revealed three electrical heart axes, which will be relevant to avoid misinterpretation of the clinical relevance of the adult zebrafish for future arrhythmia studies [90]. Magnetic resonance imaging (MRI) uses a magnetic field and radio waves to provide detailed images of the organs and tissues of the body. MRI has been increasingly employed in non-aquatic animals for cardiovascular disease, and its use has recently been shown to be possible in anesthetized zebrafish [185,186]. MRI presents the advantage of being highly resolutive, non-invasive, and suitable for morphological characterization of the cardiac chambers in zebrafish. The different methods described here provide a wide range of possibilities to measure cardiac rhythm in zebrafish embryos and adults and evaluate cardiovascular performance, gene function assays, and high content drug screening.

\section{Outlook}

The combination of genetic studies and functional genomics in zebrafish has broadened our knowledge on mechanisms of cardiac disease. Genetic studies in patients with cardiac arrhythmias have boomed, yet there exists a paucity of functional modeling of newly uncovered variants. As the ability to knock-in genetic sequences becomes more feasible and higher throughput in zebrafish [119,187-190], models expressing human variants will provide valuable insight into disease mechanisms. This approach is an especially powerful to elucidate the pathogenicity of specific variants, as highlighted above. One major challenge will be assessing the deleterious effects of non-coding variants. Often, these regions show less conservation amongst species, and thus are more challenging to interpret. However, functional biological evidence may be garnered by mutating putative genes in zebrafish identified from synteny, eQTL analysis, or chromosome capture techniques. Furthermore, understanding how epigenetic alterations, including methylation, histone modification, and chromatin remodeling, contributes to disease risk [11] will be an exciting avenue to explore.

As genetic variation may predict response to different therapies, zebrafish may be used in suppressor screens to identify novel chemical modulators of disease phenotypes or new arrhythmogenic substrates. Zebrafish carrying myl4 or plakoglobin mutations have been used in small molecule screens to identify modifiers of cardiac arrhythmia, and have identified conserved disease mechanisms in both zebrafish and mammalian models [106,126,183,191]. It will be exciting to see how zebrafish mutants carrying putative human variants respond in similar screens. These findings may provide an avenue to pharmacogenetically guide therapy for cardiac rhythm disease to yield more targeted and effective treatment strategies.

While the suitability of zebrafish to study arrhythmia is evident, caveats and limitations as mentioned above should guide interpretation as with all models of human disease. Even though zebrafish possess a smaller two-chambered heart, we have learned many lessons that have been extrapolated to understanding human heart development, disease, and regeneration. However, important species-specific parameters, including ionic currents or dependence on sarcoplasmic reticulum $\mathrm{Ca}^{2+}$ stores in excitation-contraction coupling, should be acknowledged when modeling cardiac arrhythmias and translating these findings to human disease. Nonetheless, as more genomic sequencing data from patients becomes available, the zebrafish is poised to make impactful observations to impact human health and personalized medicine.

Author Contributions: Writing—original draft preparation, S.G., J.B., J.L., M.M.C.; writing—review and editing, S.G., J.B., J.L., M.M.C.; supervision, M.M.C.; funding acquisition, M.M.C. All authors have read and agreed to the published version of the manuscript. 
Funding: This work was supported by start-up funds from the College of Medicine, University of Saskatchewan (M.M.C.). J.L. was supported by a Natural Sciences and Engineering Research Council of Canada Undergraduate Student Research Award (NSERC-USRA) and a Biomedical Summer Research Project award from the College of Medicine, University of Saskatchewan.

Acknowledgments: We thank all members of the Collins lab for critical feedback on the manuscript. Figure 2 was created with BioRender.

Conflicts of Interest: The authors declare no conflict of interest.

\section{References}

1. Campuzano, O.; Beltrán-Álvarez, P.; Iglesias, A.; Scornik, F.; Pérez, G.; Brugada, R. Genetics and cardiac channelopathies. Genet. Med. 2010, 12, 260-267. [CrossRef]

2. Campuzano, O.; Brugada, R.; Iglesias, A. Genetics of Brugada syndrome. Curr. Opin. Cardiol. 2010, 25, 210-215. [CrossRef]

3. Heijman, J.; Muna, A.P.; Veleva, T.; Molina, C.E.; Sutanto, H.; Tekook, M.; Wang, Q.; Abu-Taha, I.H.; Gorka, M.; Künzel, S.; et al. Atrial Myocyte NLRP3/CaMKII Nexus Forms a Substrate for Postoperative Atrial Fibrillation. Circ. Res. 2020, 127, 1036-1055. [CrossRef]

4. Nattel, S.; Heijman, J.; Zhou, L.; Dobrev, D. Molecular Basis of Atrial Fibrillation Pathophysiology and Therapy: A Translational Perspective. Circ. Res. 2020, 127, 51-72. [CrossRef]

5. Dobrev, D.; Aguilar, M.; Heijman, J.; Guichard, J.B.; Nattel, S. Postoperative atrial fibrillation: Mechanisms, manifestations and management. Nat. Rev. Cardiol. 2019, 16, 417-436. [CrossRef]

6. Ragab, A.A.Y.; Sitorus, G.D.S.; Brundel, B.; de Groot, N.M.S. The Genetic Puzzle of Familial Atrial Fibrillation. Front. Cardiovasc. Med. 2020, 7, 14. [CrossRef]

7. Nielsen, J.B.; Thorolfsdottir, R.B.; Fritsche, L.G.; Zhou, W.; Skov, M.W.; Graham, S.E.; Herron, T.J.; McCarthy, S.; Schmidt, E.M.; Sveinbjornsson, G.; et al. Biobank-driven genomic discovery yields new insight into atrial fibrillation biology. Nat. Genet. 2018, 50, 1234-1239. [CrossRef]

8. Andreasen, L.; Bertelsen, L.; Ghouse, J.; Lundegaard, P.R.; Ahlberg, G.; Refsgaard, L.; Rasmussen, T.B.; Eiskjær, H.; Haunsø, S.; Vejlstrup, N.; et al. Early-onset atrial fibrillation patients show reduced left ventricular ejection fraction and increased atrial fibrosis. Sci. Rep. 2020, 10, 10039. [CrossRef]

9. Goette, A.; Kalman, J.M.; Aguinaga, L.; Akar, J.; Cabrera, J.A.; Chen, S.A.; Chugh, S.S.; Corradi, D.; D'Avila, A.; Dobrev, D.; et al. EHRA/HRS/APHRS/SOLAECE expert consensus on atrial cardiomyopathies: Definition, characterization, and clinical implication. Heart Rhythm 2017, 14, e3-e40. [CrossRef]

10. Gudbjartsson, D.F.; Holm, H.; Sulem, P.; Masson, G.; Oddsson, A.; Magnusson, O.T.; Saemundsdottir, J.; Helgadottir, H.T.; Helgason, H.; Johannsdottir, H.; et al. A frameshift deletion in the sarcomere gene MYL4 causes early-onset familial atrial fibrillation. Eur. Heart J. 2017, 38, 27-34. [CrossRef]

11. Van Ouwerkerk, A.F.; Hall, A.W.; Kadow, Z.A.; Lazarevic, S.; Reyat, J.S.; Tucker, N.R.; Nadadur, R.D.; Bosada, F.M.; Bianchi, V.; Ellinor, P.T.; et al. Epigenetic and Transcriptional Networks Underlying Atrial Fibrillation. Circ. Res. 2020, 127, 34-50. [CrossRef]

12. Roselli, C.; Rienstra, M.; Ellinor, P.T. Genetics of Atrial Fibrillation in 2020: GWAS, Genome Sequencing, Polygenic Risk, and Beyond. Circ. Res. 2020, 127, 21-33. [CrossRef]

13. Van Gorp, P.R.R.; Trines, S.A.; Pijnappels, D.A.; de Vries, A.A.F. Multicellular In vitro Models of Cardiac Arrhythmias: Focus on Atrial Fibrillation. Front. Cardiovasc. Med. 2020, 7, 43. [CrossRef]

14. Mayourian, J.; Sobie, E.A.; Costa, K.D. An Introduction to Computational Modeling of Cardiac Electrophysiology and Arrhythmogenicity. Methods Mol. Biol. 2018, 1816, 17-35. [CrossRef]

15. Stainier, D.Y.; Fouquet, B.; Chen, J.N.; Warren, K.S.; Weinstein, B.M.; Meiler, S.E.; Mohideen, M.A.; Neuhauss, S.C.; Solnica-Krezel, L.; Schier, A.F.; et al. Mutations affecting the formation and function of the cardiovascular system in the zebrafish embryo. Development 1996, 123, 285-292.

16. Keegan, B.R.; Meyer, D.; Yelon, D. Organization of cardiac chamber progenitors in the zebrafish blastula. Development 2004, 131, 3081-3091. [CrossRef]

17. Yelon, D.; Horne, S.A.; Stainier, D.Y. Restricted expression of cardiac myosin genes reveals regulated aspects of heart tube assembly in zebrafish. Dev. Biol. 1999, 214, 23-37. [CrossRef]

18. Stainier, D.Y.; Lee, R.K.; Fishman, M.C. Cardiovascular development in the zebrafish. I. Myocardial fate map and heart tube formation. Development 1993, 119, 31-40.

19. Stainier, D.Y.; Fishman, M.C. Patterning the zebrafish heart tube: Acquisition of anteroposterior polarity. Dev. Biol. 1992, 153, 91-101.

20. Rohr, S.; Otten, C.; Abdelilah-Seyfried, S. Asymmetric involution of the myocardial field drives heart tube formation in zebrafish. Circ. Res. 2008, 102, e12-e19. [CrossRef]

21. Berdougo, E.; Coleman, H.; Lee, D.H.; Stainier, D.Y.; Yelon, D. Mutation of weak atrium/atrial myosin heavy chain disrupts atrial function and influences ventricular morphogenesis in zebrafish. Development 2003, 130, 6121-6129. [CrossRef]

22. Reiter, J.F.; Alexander, J.; Rodaway, A.; Yelon, D.; Patient, R.; Holder, N.; Stainier, D.Y. Gata5 is required for the development of the heart and endoderm in zebrafish. Genes Dev. 1999, 13, 2983-2995. [CrossRef] 
23. Holtzinger, A.; Evans, T. Gata5 and Gata6 are functionally redundant in zebrafish for specification of cardiomyocytes. Dev. Biol. 2007, 312, 613-622. [CrossRef]

24. Prall, O.W.; Menon, M.K.; Solloway, M.J.; Watanabe, Y.; Zaffran, S.; Bajolle, F.; Biben, C.; McBride, J.J.; Robertson, B.R.; Chaulet, H.; et al. An Nkx2-5/Bmp2/Smad1 negative feedback loop controls heart progenitor specification and proliferation. Cell 2007, 128, 947-959. [CrossRef]

25. Benson, D.W.; Silberbach, G.M.; Kavanaugh-McHugh, A.; Cottrill, C.; Zhang, Y.; Riggs, S.; Smalls, O.; Johnson, M.C.; Watson, M.S.; Seidman, J.G.; et al. Mutations in the cardiac transcription factor NKX2.5 affect diverse cardiac developmental pathways. J. Clin. Investig. 1999, 104, 1567-1573. [CrossRef]

26. Targoff, K.L.; Colombo, S.; George, V.; Schell, T.; Kim, S.H.; Solnica-Krezel, L.; Yelon, D. Nkx genes are essential for maintenance of ventricular identity. Development 2013, 140, 4203-4213. [CrossRef]

27. Yelon, D.; Ticho, B.; Halpern, M.E.; Ruvinsky, I.; Ho, R.K.; Silver, L.M.; Stainier, D.Y. The bHLH transcription factor hand2 plays parallel roles in zebrafish heart and pectoral fin development. Development 2000, 127, 2573-2582.

28. Marques, S.R.; Yelon, D. Differential requirement for BMP signaling in atrial and ventricular lineages establishes cardiac chamber proportionality. Dev. Biol. 2009, 328, 472-482. [CrossRef]

29. Deshwar, A.R.; Chng, S.C.; Ho, L.; Reversade, B.; Scott, I.C. The Apelin receptor enhances Nodal/TGF $\beta$ signaling to ensure proper cardiac development. eLife 2016, 5, e13758. [CrossRef]

30. Ueno, S.; Weidinger, G.; Osugi, T.; Kohn, A.D.; Golob, J.L.; Pabon, L.; Reinecke, H.; Moon, R.T.; Murry, C.E. Biphasic role for Wnt/beta-catenin signaling in cardiac specification in zebrafish and embryonic stem cells. Proc. Natl. Acad. Sci. USA 2007, 104, 9685-9690. [CrossRef]

31. Pradhan, A.; Zeng, X.I.; Sidhwani, P.; Marques, S.R.; George, V.; Targoff, K.L.; Chi, N.C.; Yelon, D. FGF signaling enforces cardiac chamber identity in the developing ventricle. Development 2017, 144, 1328-1338. [CrossRef]

32. Marques, S.R.; Lee, Y.; Poss, K.D.; Yelon, D. Reiterative roles for FGF signaling in the establishment of size and proportion of the zebrafish heart. Dev. Biol. 2008, 321, 397-406. [CrossRef]

33. Duong, T.B.; Holowiecki, A.; Waxman, J.S. Retinoic acid signaling restricts the size of the first heart field within the anterior lateral plate mesoderm. Dev. Biol. 2021, 473, 119-129. [CrossRef]

34. Keegan, B.R.; Feldman, J.L.; Begemann, G.; Ingham, P.W.; Yelon, D. Retinoic acid signaling restricts the cardiac progenitor pool. Science 2005, 307, 247-249. [CrossRef]

35. Stutt, N.; Song, M.; Wilson, M.D.; Scott, I.C. Cardiac specification during gastrulation-The Yellow Brick Road leading to Tinman. In Seminars in Cell E Developmental Biology; Academic Press: London, UK, 2021. [CrossRef]

36. Staudt, D.; Stainier, D. Uncovering the molecular and cellular mechanisms of heart development using the zebrafish. Annu. Rev. Genet. 2012, 46, 397-418. [CrossRef]

37. Bakkers, J. Zebrafish as a model to study cardiac development and human cardiac disease. Cardiovasc. Res. 2011, 91, 279-288. [CrossRef]

38. Chen, J.N.; van Eeden, F.J.; Warren, K.S.; Chin, A.; Nusslein-Volhard, C.; Haffter, P.; Fishman, M.C. Left-right pattern of cardiac BMP4 may drive asymmetry of the heart in zebrafish. Development 1997, 124, 4373-4382.

39. Grimes, D.T.; Patterson, V.L.; Luna-Arvizu, G.; Schottenfeld-Roames, J.; Irons, Z.H.; Burdine, R.D. Left-right asymmetric heart jogging increases the robustness of dextral heart looping in zebrafish. Dev. Biol. 2020, 459, 79-86. [CrossRef]

40. Tessadori, F.; Tsingos, E.; Colizzi, E.S.; Kruse, F.; van den Brink, S.C.; van den Boogaard, M.; Christoffels, V.M.; Merks, R.M.; Bakkers, J. Twisting of the zebrafish heart tube during cardiac looping is a tbx5-dependent and tissue-intrinsic process. eLife 2021, 10, e61733. [CrossRef]

41. Lombardo, V.A.; Heise, M.; Moghtadaei, M.; Bornhorst, D.; Männer, J.; Abdelilah-Seyfried, S. Morphogenetic control of zebrafish cardiac looping by Bmp signaling. Development 2019, 146, dev18009. [CrossRef]

42. Ocaña, O.H.; Coskun, H.; Minguillón, C.; Murawala, P.; Tanaka, E.M.; Galcerán, J.; Muñoz-Chápuli, R.; Nieto, M.A. A right-handed signalling pathway drives heart looping in vertebrates. Nature 2017, 549, 86-90. [CrossRef]

43. Noël, E.S.; Verhoeven, M.; Lagendijk, A.K.; Tessadori, F.; Smith, K.; Choorapoikayil, S.; den Hertog, J.; Bakkers, J. A Nodalindependent and tissue-intrinsic mechanism controls heart-looping chirality. Nat. Commun. 2013, 4, 2754. [CrossRef]

44. Veerkamp, J.; Rudolph, F.; Cseresnyes, Z.; Priller, F.; Otten, C.; Renz, M.; Schaefer, L.; Abdelilah-Seyfried, S. Unilateral dampening of Bmp activity by nodal generates cardiac left-right asymmetry. Dev. Cell 2013, 24, 660-667. [CrossRef]

45. Smith, K.A.; Chocron, S.; von der Hardt, S.; de Pater, E.; Soufan, A.; Bussmann, J.; Schulte-Merker, S.; Hammerschmidt, M.; Bakkers, J. Rotation and asymmetric development of the zebrafish heart requires directed migration of cardiac progenitor cells. Dev. Cell 2008, 14, 287-297. [CrossRef]

46. Auman, H.J.; Coleman, H.; Riley, H.E.; Olale, F.; Tsai, H.J.; Yelon, D. Functional modulation of cardiac form through regionally confined cell shape changes. PLoS Biol. 2007, 5, e53. [CrossRef]

47. Grassini, D.R.; da Silva, J.; Hall, T.E.; Baillie, G.J.; Simons, C.; Parton, R.G.; Hogan, B.M.; Smith, K.A. Myosin Vb is required for correct trafficking of N-cadherin and cardiac chamber ballooning. Dev. Dyn. 2019, 248, 284-295. [CrossRef]

48. Derrick, C.J.; Pollitt, E.J.G.; Sanchez Sevilla Uruchurtu, A.; Hussein, F.; Grierson, A.J.; Noël, E.S. Lamb1a regulates atrial growth by limiting second heart field addition during zebrafish heart development. Development 2021, 148, dev199691. [CrossRef] 
49. Bornhorst, D.; Xia, P.; Nakajima, H.; Dingare, C.; Herzog, W.; Lecaudey, V.; Mochizuki, N.; Heisenberg, C.P.; Yelon, D.; Abdelilah-Seyfried, S. Biomechanical signaling within the developing zebrafish heart attunes endocardial growth to myocardial chamber dimensions. Nat. Commun. 2019, 10, 4113. [CrossRef]

50. Gunawan, F.; Gentile, A.; Fukuda, R.; Tsedeke, A.T.; Jimenez-Amilburu, V.; Ramadass, R.; Iida, A.; Sehara-Fujisawa, A.; Stainier, D.Y.R. Focal adhesions are essential to drive zebrafish heart valve morphogenesis. J. Cell Biol. 2019, 218, 1039-1054. [CrossRef]

51. Pestel, J.; Ramadass, R.; Gauvrit, S.; Helker, C.; Herzog, W.; Stainier, D.Y. Real-time 3D visualization of cellular rearrangements during cardiac valve formation. Development 2016, 143, 2217-2227. [CrossRef]

52. Beis, D.; Bartman, T.; Jin, S.W.; Scott, I.C.; D'Amico, L.A.; Ober, E.A.; Verkade, H.; Frantsve, J.; Field, H.A.; Wehman, A.; et al. Genetic and cellular analyses of zebrafish atrioventricular cushion and valve development. Development 2005, 132, 4193-4204. [CrossRef]

53. Gunawan, F.; Gentile, A.; Gauvrit, S.; Stainier, D.Y.R.; Bensimon-Brito, A. Nfatc1 Promotes Interstitial Cell Formation During Cardiac Valve Development in Zebrafish. Circ. Res. 2020, 126, 968-984. [CrossRef]

54. Scherz, P.J.; Huisken, J.; Sahai-Hernandez, P.; Stainier, D.Y. High-speed imaging of developing heart valves reveals interplay of morphogenesis and function. Development 2008, 135, 1179-1187. [CrossRef]

55. Fukui, H.; Chow, R.W.; Xie, J.; Foo, Y.Y.; Yap, C.H.; Minc, N.; Mochizuki, N.; Vermot, J. Bioelectric signaling and the control of cardiac cell identity in response to mechanical forces. Science 2021, 374, 351-354. [CrossRef]

56. Peshkovsky, C.; Totong, R.; Yelon, D. Dependence of cardiac trabeculation on neuregulin signaling and blood flow in zebrafish. Dev. Dyn. 2011, 240, 446-456. [CrossRef]

57. Liu, J.; Bressan, M.; Hassel, D.; Huisken, J.; Staudt, D.; Kikuchi, K.; Poss, K.D.; Mikawa, T.; Stainier, D.Y. A dual role for ErbB2 signaling in cardiac trabeculation. Development 2010, 137, 3867-3875. [CrossRef]

58. Jiménez-Amilburu, V.; Rasouli, S.J.; Staudt, D.W.; Nakajima, H.; Chiba, A.; Mochizuki, N.; Stainier, D.Y.R. In Vivo Visualization of Cardiomyocyte Apicobasal Polarity Reveals Epithelial to Mesenchymal-like Transition during Cardiac Trabeculation. Cell Rep. 2016, 17, 2687-2699. [CrossRef]

59. Staudt, D.W.; Liu, J.; Thorn, K.S.; Stuurman, N.; Liebling, M.; Stainier, D.Y. High-resolution imaging of cardiomyocyte behavior reveals two distinct steps in ventricular trabeculation. Development 2014, 141, 585-593. [CrossRef]

60. Rasouli, S.J.; Stainier, D.Y.R. Regulation of cardiomyocyte behavior in zebrafish trabeculation by Neuregulin 2a signaling Nat. Commun. 2017, 8, 15281. [CrossRef]

61. Fukuda, R.; Aharonov, A.; Ong, Y.T.; Stone, O.A.; El-Brolosy, M.; Maischein, H.M.; Potente, M.; Tzahor, E.; Stainier, D.Y. Metabolic modulation regulates cardiac wall morphogenesis in zebrafish. eLife 2019, 8, e50161. [CrossRef]

62. Priya, R.; Allanki, S.; Gentile, A.; Mansingh, S.; Uribe, V.; Maischein, H.M.; Stainier, D.Y.R. Tension heterogeneity directs form and fate to pattern the myocardial wall. Nature 2020, 588, 130-134. [CrossRef]

63. Samsa, L.A.; Givens, C.; Tzima, E.; Stainier, D.Y.; Qian, L.; Liu, J. Cardiac contraction activates endocardial Notch signaling to modulate chamber maturation in zebrafish. Development 2015, 142, 4080-4091. [CrossRef]

64. Chi, N.C.; Shaw, R.M.; Jungblut, B.; Huisken, J.; Ferrer, T.; Arnaout, R.; Scott, I.; Beis, D.; Xiao, T.; Baier, H.; et al. Genetic and physiologic dissection of the vertebrate cardiac conduction system. PLoS Biol. 2008, 6, e109. [CrossRef]

65. Panáková, D.; Werdich, A.A.; Macrae, C.A. Wnt11 patterns a myocardial electrical gradient through regulation of the L-type $\mathrm{Ca}(2+)$ channel. Nature 2010, 466, 874-878. [CrossRef]

66. Arrenberg, A.B.; Stainier, D.Y.; Baier, H.; Huisken, J. Optogenetic control of cardiac function. Science 2010, 330, 971-974. [CrossRef]

67. Tessadori, F.; van Weerd, J.H.; Burkhard, S.B.; Verkerk, A.O.; de Pater, E.; Boukens, B.J.; Vink, A.; Christoffels, V.M.; Bakkers, J. Identification and functional characterization of cardiac pacemaker cells in zebrafish. PLoS ONE 2012, 7, e47644. [CrossRef]

68. Sedmera, D.; Reckova, M.; de Almeida, A.; Sedmerova, M.; Biermann, M.; Volejnik, J.; Sarre, A.; Raddatz, E.; McCarthy, R.A.; Gourdie, R.G.; et al. Functional and morphological evidence for a ventricular conduction system in zebrafish and Xenopus hearts. Am. J. Physiol. Heart Circ. Physiol. 2003, 284, H1152-H1160. [CrossRef]

69. Milan, D.J.; Giokas, A.C.; Serluca, F.C.; Peterson, R.T.; MacRae, C.A. Notch1b and neuregulin are required for specification of central cardiac conduction tissue. Development 2006, 133, 1125-1132. [CrossRef]

70. van Eif, V.W.W.; Devalla, H.D.; Boink, G.J.J.; Christoffels, V.M. Transcriptional regulation of the cardiac conduction system. Nat. Rev. Cardiol. 2018, 15, 617-630. [CrossRef]

71. Mohan, R.A.; Bosada, F.M.; van Weerd, J.H.; van Duijvenboden, K.; Wang, J.; Mommersteeg, M.T.M.; Hooijkaas, I.B.; Wakker, V.; de Gier-de Vries, C.; Coronel, R.; et al. T-box transcription factor 3 governs a transcriptional program for the function of the mouse atrioventricular conduction system. Proc. Natl. Acad. Sci. USA 2020, 117, 18617-18626. [CrossRef]

72. Ammirabile, G.; Tessari, A.; Pignataro, V.; Szumska, D.; Sutera Sardo, F.; Benes, J., Jr.; Balistreri, M.; Bhattacharya, S.; Sedmera, D.; Campione, M. Pitx2 confers left morphological, molecular, and functional identity to the sinus venosus myocardium. Cardiovasc. Res. 2012, 93, 291-301. [CrossRef]

73. Wang, J.; Klysik, E.; Sood, S.; Johnson, R.L.; Wehrens, X.H.; Martin, J.F. Pitx2 prevents susceptibility to atrial arrhythmias by inhibiting left-sided pacemaker specification. Proc. Natl. Acad. Sci. USA 2010, 107, 9753-9758. [CrossRef]

74. Mommersteeg, M.T.; Hoogaars, W.M.; Prall, O.W.; de Gier-de Vries, C.; Wiese, C.; Clout, D.E.; Papaioannou, V.E.; Brown, N.A.; Harvey, R.P.; Moorman, A.F.; et al. Molecular pathway for the localized formation of the sinoatrial node. Circ. Res. 2007, 100, 354-362. [CrossRef] 
75. Espinoza-Lewis, R.A.; Yu, L.; He, F.; Liu, H.; Tang, R.; Shi, J.; Sun, X.; Martin, J.F.; Wang, D.; Yang, J.; et al. Shox2 is essential for the differentiation of cardiac pacemaker cells by repressing Nkx2-5. Dev. Biol. 2009, 327, 376-385. [CrossRef]

76. Sizarov, A.; Devalla, H.D.; Anderson, R.H.; Passier, R.; Christoffels, V.M.; Moorman, A.F. Molecular analysis of patterning of conduction tissues in the developing human heart. Circ. Arrhythm Electrophysiol. 2011, 4, 532-542. [CrossRef]

77. Mommersteeg, M.T.; Domínguez, J.N.; Wiese, C.; Norden, J.; de Gier-de Vries, C.; Burch, J.B.; Kispert, A.; Brown, N.A.; Moorman, A.F.; Christoffels, V.M. The sinus venosus progenitors separate and diversify from the first and second heart fields early in development. Cardiovasc. Res. 2010, 87, 92-101. [CrossRef]

78. Sun, Y.; Liang, X.; Najafi, N.; Cass, M.; Lin, L.; Cai, C.L.; Chen, J.; Evans, S.M. Islet 1 is expressed in distinct cardiovascular lineages, including pacemaker and coronary vascular cells. Dev Biol 2007, 304, 286-296. [CrossRef]

79. Nadadur, R.D.; Broman, M.T.; Boukens, B.; Mazurek, S.R.; Yang, X.; van den Boogaard, M.; Bekeny, J.; Gadek, M.; Ward, T.; Zhang, M.; et al. Pitx2 modulates a Tbx5-dependent gene regulatory network to maintain atrial rhythm. Sci. Transl. Med. 2016, 8, 354ra115. [CrossRef]

80. Burnicka-Turek, O.; Broman, M.T.; Steimle, J.D.; Boukens, B.J.; Petrenko, N.B.; Ikegami, K.; Nadadur, R.D.; Qiao, Y.; Arnolds, D.E.; Yang, X.H.; et al. Transcriptional Patterning of the Ventricular Cardiac Conduction System. Circ. Res. 2020, 127, e94-e106. [CrossRef]

81. Epstein, J.A.; Aghajanian, H.; Singh, M.K. Semaphorin Signaling in Cardiovascular Development. Cell Metab. 2015, 21, 163-173. [CrossRef]

82. Sun, Q.; Liu, S.; Liu, K.; Jiao, K. Role of Semaphorin Signaling During Cardiovascular Development. J. Am. Heart Assoc. 2018, 7, e008853. [CrossRef]

83. Burkhard, S.B.; Bakkers, J. Spatially resolved RNA-sequencing of the embryonic heart identifies a role for Wnt/beta-catenin signaling in autonomic control of heart rate. eLife 2018, 7, e31515. [CrossRef]

84. Minhas, R.; Loeffler-Wirth, H.; Siddiqui, Y.H.; Obrębski, T.; Vashisht, S.; Nahia, K.A.; Paterek, A.; Brzozowska, A.; Bugajski, L.; Piwocka, K.; et al. Transcriptome profile of the sinoatrial ring reveals conserved and novel genetic programs of the zebrafish pacemaker. BMC Genom. 2021, 22, 715. [CrossRef]

85. Abu Nahia, K.; Migdał, M.; Quinn, T.A.; Poon, K.-L.; Łapiński, M.; Sulej, A.; Liu, J.; Mondal, S.S.; Pawlak, M.; Bugajski, Ł.; et al. Genomic and physiological analyses of the zebrafish atrioventricular canal reveal molecular building blocks of the secondary pacemaker region. Cell. Mol. Life Sci. 2021, 78, 6669-6687. [CrossRef]

86. Sampurna, B.P.; Audira, G.; Juniardi, S.; Lai, Y.-H.; Hsiao, C.-D. A Simple ImageJ-Based Method to Measure Cardiac Rhythm in Zebrafish Embryos. Inventions 2018, 3, 21.

87. Zhao, Y.; Yun, M.; Nguyen, S.A.; Tran, M.; Nguyen, T.P. In Vivo Surface Electrocardiography for Adult Zebrafish. J. Vis. Exp. 2019, 150, e60011. [CrossRef]

88. Milan, D.J.; Jones, I.L.; Ellinor, P.T.; MacRae, C.A. In vivo recording of adult zebrafish electrocardiogram and assessment of drug-induced QT prolongation. Am. J. Physiol. Heart Circ. Physiol. 2006, 291, H269-H273. [CrossRef]

89. Echeazarra, L.; Hortigón-Vinagre, M.P.; Casis, O.; Gallego, M. Adult and Developing Zebrafish as Suitable Models for Cardiac Electrophysiology and Pathology in Research and Industry. Front. Physiol. 2021, 11, 1692. [CrossRef]

90. Zhao, Y.; Chen, C.; Yun, M.; Issa, T.; Lin, A.; Nguyen, T.P. Constructing Adult Zebrafish Einthoven's Triangle to Define Electrical Heart Axes. Front. Physiol. 2021, 12, 708938. [CrossRef]

91. Nemtsas, P.; Wettwer, E.; Christ, T.; Weidinger, G.; Ravens, U. Adult zebrafish heart as a model for human heart? An electrophysiological study. J. Mol. Cell. Cardiol. 2010, 48, 161-171. [CrossRef]

92. Howe, K.; Clark, M.D.; Torroja, C.F.; Torrance, J.; Berthelot, C.; Muffato, M.; Collins, J.E.; Humphray, S.; McLaren, K.; Matthews, L.; et al. The zebrafish reference genome sequence and its relationship to the human genome. Nature 2013, 496, 498-503. [CrossRef]

93. Genge, C.E.; Lin, E.; Lee, L.; Sheng, X.; Rayani, K.; Gunawan, M.; Stevens, C.M.; Li, A.Y.; Talab, S.S.; Claydon, T.W.; et al. The Zebrafish Heart as a Model of Mammalian Cardiac Function. Rev. Physiol. Biochem. Pharmacol. 2016, 171, 99-136. [CrossRef]

94. Alday, A.; Alonso, H.; Gallego, M.; Urrutia, J.; Letamendia, A.; Callol, C.; Casis, O. Ionic channels underlying the ventricular action potential in zebrafish embryo. Pharmacol. Res. 2014, 84, 26-31. [CrossRef]

95. Leong, I.U.; Skinner, J.R.; Shelling, A.N.; Love, D.R. Zebrafish as a model for long QT syndrome: The evidence and the means of manipulating zebrafish gene expression. Acta Physiol. 2010, 199, 257-276. [CrossRef]

96. Haverinen, J.; Hassinen, M.; Korajoki, H.; Vornanen, M. Cardiac voltage-gated sodium channel expression and electrophysiological characterization of the sodium current in the zebrafish (Danio rerio) ventricle. Prog. Biophys. Mol. Biol. 2018, 138, 59-68. [CrossRef]

97. Hassinen, M.; Haverinen, J.; Hardy, M.E.; Shiels, H.A.; Vornanen, M. Inward rectifier potassium current (I K1) and Kir2 composition of the zebrafish (Danio rerio) heart. Pflug. Arch. 2015, 467, 2437-2446. [CrossRef]

98. Abramochkin, D.V.; Hassinen, M.; Vornanen, M. Transcripts of Kv7.1 and MinK channels and slow delayed rectifier K(+) current (I(Ks)) are expressed in zebrafish (Danio rerio) heart. Pflug. Arch. 2018, 470, 1753-1764. [CrossRef]

99. Brette, F.; Luxan, G.; Cros, C.; Dixey, H.; Wilson, C.; Shiels, H.A. Characterization of isolated ventricular myocytes from adult zebrafish (Danio rerio). Biochem. Biophys. Res. Commun. 2008, 374, 143-146. [CrossRef]

100. Bovo, E.; Dvornikov, A.V.; Mazurek, S.R.; de Tombe, P.P.; Zima, A.V. Mechanisms of $\mathrm{Ca}^{2}+$ handling in zebrafish ventricular myocytes. Pflug. Arch. 2013, 465, 1775-1784. [CrossRef]

101. Voigt, N.; Heijman, J.; Wang, Q.; Chiang, D.Y.; Li, N.; Karck, M.; Wehrens, X.H.T.; Nattel, S.; Dobrev, D. Cellular and molecular mechanisms of atrial arrhythmogenesis in patients with paroxysmal atrial fibrillation. Circulation 2014, 129, 145-156. [CrossRef] 
102. Chen, J.N.; Haffter, P.; Odenthal, J.; Vogelsang, E.; Brand, M.; van Eeden, F.J.; Furutani-Seiki, M.; Granato, M.; Hammerschmidt, M.; Heisenberg, C.P.; et al. Mutations affecting the cardiovascular system and other internal organs in zebrafish. Development 1996, 123, 293-302.

103. Pott, A.; Bock, S.; Berger, I.M.; Frese, K.; Dahme, T.; Keßler, M.; Rinné, S.; Decher, N.; Just, S.; Rottbauer, W. Mutation of the $\mathrm{Na}(+) / \mathrm{K}(+)$-ATPase Atp1a1a.1 causes QT interval prolongation and bradycardia in zebrafish. J. Mol. Cell. Cardiol. 2018, $120,42-52$. [CrossRef]

104. Rottbauer, W.; Baker, K.; Wo, Z.G.; Mohideen, M.A.; Cantiello, H.F.; Fishman, M.C. Growth and function of the embryonic heart depend upon the cardiac-specific L-type calcium channel alpha1 subunit. Dev. Cell 2001, 1, 265-275. [CrossRef]

105. Orr, N.; Arnaout, R.; Gula, L.J.; Spears, D.A.; Leong-Sit, P.; Li, Q.; Tarhuni, W.; Reischauer, S.; Chauhan, V.S.; Borkovich, M.; et al. A mutation in the atrial-specific myosin light chain gene (MYL4) causes familial atrial fibrillation. Nat. Commun. 2016, 7, 11303. [CrossRef]

106. Ghazizadeh, Z.; Kiviniemi, T.; Olafsson, S.; Plotnick, D.; Beerens, M.E.; Zhang, K.; Gillon, L.; Steinbaugh, M.J.; Barrera, V.; Sui, S.H.; et al. Metastable Atrial State Underlies the Primary Genetic Substrate for MYL4 Mutation-Associated Atrial Fibrillation. Circulation 2020, 141, 301-312. [CrossRef]

107. Rattka, M.; Westphal, S.; Gahr, B.M.; Just, S.; Rottbauer, W. Spen deficiency interferes with Connexin 43 expression and leads to heart failure in zebrafish. J. Mol. Cell. Cardiol. 2021, 155, 25-35. [CrossRef]

108. Chi, N.C.; Shaw, R.M.; De Val, S.; Kang, G.; Jan, L.Y.; Black, B.L.; Stainier, D.Y. Foxn4 directly regulates tbx2b expression and atrioventricular canal formation. Genes Dev. 2008, 22, 734-739. [CrossRef]

109. Chi, N.C.; Bussen, M.; Brand-Arzamendi, K.; Ding, C.; Olgin, J.E.; Shaw, R.M.; Martin, G.R.; Stainier, D.Y. Cardiac conduction is required to preserve cardiac chamber morphology. Proc. Natl. Acad. Sci. USA 2010, 107, 14662-14667. [CrossRef]

110. Jou, C.J.; Arrington, C.B.; Barnett, S.; Shen, J.; Cho, S.; Sheng, X.; McCullagh, P.C.; Bowles, N.E.; Pribble, C.M.; Saarel, E.V.; et al. A Functional Assay for Sick Sinus Syndrome Genetic Variants. Cell. Physiol. Biochem. 2017, 42, 2021-2029. [CrossRef]

111. De Pater, E.; Clijsters, L.; Marques, S.R.; Lin, Y.F.; Garavito-Aguilar, Z.V.; Yelon, D.; Bakkers, J. Distinct phases of cardiomyocyte differentiation regulate growth of the zebrafish heart. Development 2009, 136, 1633-1641. [CrossRef]

112. Langheinrich, U.; Vacun, G.; Wagner, T. Zebrafish embryos express an orthologue of HERG and are sensitive toward a range of QT-prolonging drugs inducing severe arrhythmia. Toxicol. Appl. Pharmacol. 2003, 193, 370-382. [CrossRef]

113. Hassel, D.; Scholz, E.P.; Trano, N.; Friedrich, O.; Just, S.; Meder, B.; Weiss, D.L.; Zitron, E.; Marquart, S.; Vogel, B.; et al. Deficient zebrafish ether-à-go-go-related gene channel gating causes short-QT syndrome in zebrafish reggae mutants. Circulation 2008, 117, 866-875. [CrossRef]

114. Pineda, S.; Nikolova-Krstevski, V.; Leimena, C.; Atkinson, A.J.; Altekoester, A.K.; Cox, C.D.; Jacoby, A.; Huttner, I.G.; Ju, Y.K.; Soka, M.; et al. Conserved Role of the Large Conductance Calcium-Activated Potassium Channel, K(Ca)1.1, in Sinus Node Function and Arrhythmia Risk. Circ. Genom. Precis Med. 2021, 14, e003144. [CrossRef]

115. Langenbacher, A.D.; Shimizu, H.; Hsu, W.; Zhao, Y.; Borges, A.; Koehler, C.; Chen, J.N. Mitochondrial Calcium Uniporter Deficiency in Zebrafish Causes Cardiomyopathy With Arrhythmia. Front. Physiol. 2020, 11, 617492. [CrossRef]

116. Harrington, J.K.; Sorabella, R.; Tercek, A.; Isler, J.R.; Targoff, K.L. Nkx2.5 is essential to establish normal heart rate variability in the zebrafish embryo. Am. J. Physiol. Regul. Integr. Comp. Physiol. 2017, 313, R265-R271. [CrossRef]

117. Collins, M.M.; Ahlberg, G.; Hansen, C.V.; Guenther, S.; Marín-Juez, R.; Sokol, A.M.; El-Sammak, H.; Piesker, J.; Hellsten, Y.; Olesen, M.S.; et al. Early sarcomere and metabolic defects in a zebrafish pitx2c cardiac arrhythmia model. Proc. Natl. Acad. Sci. USA 2019, 116, 24115-24121. [CrossRef]

118. Kamel, S.M.; van Opbergen, C.J.M.; Koopman, C.D.; Verkerk, A.O.; Boukens, B.J.D.; de Jonge, B.; Onderwater, Y.L.; van Alebeek, E.; Chocron, S.; Polidoro Pontalti, C.; et al. Istaroxime treatment ameliorates calcium dysregulation in a zebrafish model of phospholamban R14del cardiomyopathy. Nat. Commun. 2021, 12, 7151. [CrossRef]

119. Tessadori, F.; Roessler, H.I.; Savelberg, S.M.C.; Chocron, S.; Kamel, S.M.; Duran, K.J.; van Haelst, M.M.; van Haaften, G.; Bakkers, J. Effective CRISPR/Cas9-based nucleotide editing in zebrafish to model human genetic cardiovascular disorders. Dis. Model Mech. 2018, 11, dmm035469. [CrossRef]

120. Huttner, I.G.; Trivedi, G.; Jacoby, A.; Mann, S.A.; Vandenberg, J.I.; Fatkin, D. A transgenic zebrafish model of a human cardiac sodium channel mutation exhibits bradycardia, conduction-system abnormalities and early death. J. Mol. Cell. Cardiol. 2013, 61, 123-132. [CrossRef]

121. Ebert, A.M.; Hume, G.L.; Warren, K.S.; Cook, N.P.; Burns, C.G.; Mohideen, M.A.; Siegal, G.; Yelon, D.; Fishman, M.C.; Garrity, D.M. Calcium extrusion is critical for cardiac morphogenesis and rhythm in embryonic zebrafish hearts. Proc. Natl. Acad. Sci. USA 2005, 102, 17705-17710. [CrossRef]

122. Garrity, D.M.; Childs, S.; Fishman, M.C. The heartstrings mutation in zebrafish causes heart/fin Tbx5 deficiency syndrome. Development 2002, 129, 4635-4645.

123. Koopman, C.D.; De Angelis, J.; Iyer, S.P.; Verkerk, A.O.; Da Silva, J.; Berecki, G.; Jeanes, A.; Baillie, G.J.; Paterson, S.; Uribe, V.; et al. The zebrafish grime mutant uncovers an evolutionarily conserved role for Tmem161b in the control of cardiac rhythm. Proc. Natl. Acad. Sci. USA 2021, 118, e2018220118. [CrossRef]

124. Ahlberg, G.; Refsgaard, L.; Lundegaard, P.R.; Andreasen, L.; Ranthe, M.F.; Linscheid, N.; Nielsen, J.B.; Melbye, M.; Haunso, S.; Sajadieh, A.; et al. Rare truncating variants in the sarcomeric protein titin associate with familial and early-onset atrial fibrillation. Nat. Commun. 2018, 9, 4316. [CrossRef] 
125. Ackerman, M.J.; Priori, S.G.; Willems, S.; Berul, C.; Brugada, R.; Calkins, H.; Camm, A.J.; Ellinor, P.T.; Gollob, M.; Hamilton, R.; et al. HRS/EHRA expert consensus statement on the state of genetic testing for the channelopathies and cardiomyopathies this document was developed as a partnership between the Heart Rhythm Society (HRS) and the European Heart Rhythm Association (EHRA). Heart Rhythm 2011, 8, 1308-1339. [CrossRef]

126. Peal, D.S.; Mills, R.W.; Lynch, S.N.; Mosley, J.M.; Lim, E.; Ellinor, P.T.; January, C.T.; Peterson, R.T.; Milan, D.J. Novel chemical suppressors of long QT syndrome identified by an in vivo functional screen. Circulation 2011, 123, 23-30. [CrossRef]

127. Yan, J.; Li, H.; Bu, H.; Jiao, K.; Zhang, A.X.; Le, T.; Cao, H.; Li, Y.; Ding, Y.; Xu, X. Aging-associated sinus arrest and sick sinus syndrome in adult zebrafish. PLoS ONE 2020, 15, e0232457. [CrossRef]

128. Simpson, K.E.; Venkateshappa, R.; Pang, Z.K.; Faizi, S.; Tibbits, G.F.; Claydon, T.W. Utility of Zebrafish Models of Acquired and Inherited Long QT Syndrome. Front. Physiol. 2021, 11, 7815. [CrossRef]

129. Walsh, R.; Adler, A.; Amin, A.S.; Abiusi, E.; Care, M.; Bikker, H.; Amenta, S.; Feilotter, H.; Nannenberg, E.A.; Mazzarotto, F.; et al. Evaluation of gene validity for CPVT and short QT syndrome in sudden arrhythmic death. Eur. Heart J. 2021. [CrossRef]

130. Ng, K.; Titus, E.W.; Lieve, K.V.; Roston, T.M.; Mazzanti, A.; Deiter, F.H.; Denjoy, I.; Ingles, J.; Till, J.; Robyns, T.; et al. An International Multicenter Evaluation of Inheritance Patterns, Arrhythmic Risks, and Underlying Mechanisms of CASQ2Catecholaminergic Polymorphic Ventricular Tachycardia. Circulation 2020, 142, 932-947. [CrossRef]

131. Priori, S.G.; Napolitano, C.; Tiso, N.; Memmi, M.; Vignati, G.; Bloise, R.; Sorrentino, V.; Danieli, G.A. Mutations in the cardiac ryanodine receptor gene (hRyR2) underlie catecholaminergic polymorphic ventricular tachycardia. Circulation 2001, 103, 196-200. [CrossRef]

132. Furlan, S.; Mosole, S.; Murgia, M.; Nagaraj, N.; Argenton, F.; Volpe, P.; Nori, A. Calsequestrins in skeletal and cardiac muscle from adult Danio rerio. J. Muscle Res. Cell Motil. 2016, 37, 27-39. [CrossRef]

133. Wu, H.H.; Brennan, C.; Ashworth, R. Ryanodine receptors, a family of intracellular calcium ion channels, are expressed throughout early vertebrate development. BMC Res. Notes 2011, 4, 541. [CrossRef]

134. Søndergaard, M.T.; Sorensen, A.B.; Skov, L.L.; Kjaer-Sorensen, K.; Bauer, M.C.; Nyegaard, M.; Linse, S.; Oxvig, C.; Overgaard, M.T. Calmodulin mutations causing catecholaminergic polymorphic ventricular tachycardia confer opposing functional and biophysical molecular changes. FEBS J. 2015, 282, 803-816. [CrossRef]

135. Milanesi, R.; Baruscotti, M.; Gnecchi-Ruscone, T.; DiFrancesco, D. Familial sinus bradycardia associated with a mutation in the cardiac pacemaker channel. N. Engl. J. Med. 2006, 354, 151-157. [CrossRef]

136. Anderson, J.B.; Benson, D.W. Genetics of Sick Sinus Syndrome. Card. Electrophysiol. Clin. 2010, 2, 499-507. [CrossRef]

137. Baker, K.; Warren, K.S.; Yellen, G.; Fishman, M.C. Defective "pacemaker" current (Ih) in a zebrafish mutant with a slow heart rate. Proc. Natl. Acad. Sci. USA 1997, 94, 4554-4559. [CrossRef]

138. Warren, K.S.; Baker, K.; Fishman, M.C. The slow mo mutation reduces pacemaker current and heart rate in adult zebrafish. Am J. Physiol. Heart Circ. Physiol. 2001, 281, H1711-H1719. [CrossRef]

139. Wu, S.H.; Wang, X.H.; Xu, Y.J.; Gu, J.N.; Yang, C.X.; Qiao, Q.; Guo, X.J.; Guo, Y.H.; Qiu, X.B.; Jiang, W.F.; et al. ISL1 loss-of-function variation causes familial atrial fibrillation. Eur. J. Med. Genet. 2020, 63, 104029. [CrossRef]

140. Laforest, B.; Dai, W.; Tyan, L.; Lazarevic, S.; Shen, K.M.; Gadek, M.; Broman, M.T.; Weber, C.R.; Moskowitz, I.P. Atrial fibrillation risk loci interact to modulate Ca2+-dependent atrial rhythm homeostasis. J. Clin. Investig. 2019, 129, 4937-4950. [CrossRef]

141. Roselli, C.; Chaffin, M.D.; Weng, L.-C.; Aeschbacher, S.; Ahlberg, G.; Albert, C.M.; Almgren, P.; Alonso, A.; Anderson, C.D.; Aragam, K.G.; et al. Multi-ethnic genome-wide association study for atrial fibrillation. Nat. Genet. 2018, 50, 1225-1233. [CrossRef]

142. Liang, X.; Zhang, Q.; Cattaneo, P.; Zhuang, S.; Gong, X.; Spann, N.J.; Jiang, C.; Cao, X.; Zhao, X.; Zhang, X.; et al. Transcription factor ISL1 is essential for pacemaker development and function. J. Clin. Invest. 2015, 125, 3256-3268. [CrossRef]

143. Li, N.; Wang, Z.S.; Wang, X.H.; Xu, Y.J.; Qiao, Q.; Li, X.M.; Di, R.M.; Guo, X.J.; Li, R.G.; Zhang, M.; et al. A SHOX2 loss-of-function mutation underlying familial atrial fibrillation. Int. J. Med. Sci. 2018, 15, 1564-1572. [CrossRef]

144. Hoffmann, S.; Clauss, S.; Berger, I.M.; Weiß, B.; Montalbano, A.; Röth, R.; Bucher, M.; Klier, I.; Wakili, R.; Seitz, H.; et al. Coding and non-coding variants in the SHOX2 gene in patients with early-onset atrial fibrillation. Basic Res. Cardiol. 2016, 111, 36. [CrossRef]

145. Hoffmann, S.; Paone, C.; Sumer, S.A.; Diebold, S.; Weiss, B.; Roeth, R.; Clauss, S.; Klier, I.; Kääb, S.; Schulz, A.; et al. Functional Characterization of Rare Variants in the SHOX2 Gene Identified in Sinus Node Dysfunction and Atrial Fibrillation. Front. Genet. 2019, 10, 648. [CrossRef]

146. George, V.; Colombo, S.; Targoff, K.L. An early requirement for nkx2.5 ensures the first and second heart field ventricular identity and cardiac function into adulthood. Dev. Biol. 2015, 400, 10-22. [CrossRef]

147. Begemann, G.; Ingham, P.W. Developmental regulation of Tbx5 in zebrafish embryogenesis. Mech. Dev. 2000, 90, 299-304. [CrossRef]

148. Ruvinsky, I.; Oates, A.C.; Silver, L.M.; Ho, R.K. The evolution of paired appendages in vertebrates: T-box genes in the zebrafish. Dev. Genes Evol. 2000, 210, 82-91. [CrossRef]

149. Basson, C.T.; Bachinsky, D.R.; Lin, R.C.; Levi, T.; Elkins, J.A.; Soults, J.; Grayzel, D.; Kroumpouzou, E.; Traill, T.A.; Leblanc-Straceski, J.; et al. Mutations in human TBX5 [corrected] cause limb and cardiac malformation in Holt-Oram syndrome. Nat. Genet. 1997, 15, 30-35. [CrossRef] 
150. Li, Q.Y.; Newbury-Ecob, R.A.; Terrett, J.A.; Wilson, D.I.; Curtis, A.R.; Yi, C.H.; Gebuhr, T.; Bullen, P.J.; Robson, S.C.; Strachan, T.; et al. Holt-Oram syndrome is caused by mutations in TBX5, a member of the Brachyury (T) gene family. Nat. Genet. 1997, 15, 21-29. [CrossRef]

151. Gudbjartsson, D.F.; Arnar, D.O.; Helgadottir, A.; Gretarsdottir, S.; Holm, H.; Sigurdsson, A.; Jonasdottir, A.; Baker, A.; Thorleifsson, G.; Kristjansson, K.; et al. Variants conferring risk of atrial fibrillation on chromosome 4q25. Nature 2007, 448, 353-357. [CrossRef]

152. Syeda, F.; Kirchhof, P.; Fabritz, L. PITX2-dependent gene regulation in atrial fibrillation and rhythm control. J. Physiol. 2017, 595, 4019-4026. [CrossRef]

153. Kirchhof, P.; Kahr, P.C.; Kaese, S.; Piccini, I.; Vokshi, I.; Scheld, H.H.; Rotering, H.; Fortmueller, L.; Laakmann, S.; Verheule, S.; et al. PITX2c is expressed in the adult left atrium, and reducing Pitx2c expression promotes atrial fibrillation inducibility and complex changes in gene expression. Circ. Cardiovasc. Genet. 2011, 4, 123-133. [CrossRef]

154. Korantzopoulos, P.; Letsas, K.; Fragakis, N.; Tse, G.; Liu, T. Oxidative stress and atrial fibrillation: An update. Free Radic. Res. 2018, 52, 1199-1209. [CrossRef]

155. Dai, D.-F.; Rabinovitch, P.S. Cardiac Aging in Mice and Humans: The Role of Mitochondrial Oxidative Stress. Trends Cardiovasc. Med. 2009, 19, 213-220. [CrossRef]

156. Lubitz, S.A.; Brody, J.A.; Bihlmeyer, N.A.; Roselli, C.; Weng, L.-C.; Christophersen, I.E.; Alonso, A.; Boerwinkle, E.; Gibbs, R.A.; Bis, J.C.; et al. Whole Exome Sequencing in Atrial Fibrillation. PLoS Genet. 2016, 12, e1006284. [CrossRef]

157. Costa, S.; Cerrone, M.; Saguner, A.M.; Brunckhorst, C.; Delmar, M.; Duru, F. Arrhythmogenic cardiomyopathy: An in-depth look at molecular mechanisms and clinical correlates. Trends Cardiovasc. Med. 2021, 31, 395-402. [CrossRef]

158. Beqqali, A.; Monshouwer-Kloots, J.; Monteiro, R.; Welling, M.; Bakkers, J.; Ehler, E.; Verkleij, A.; Mummery, C.; Passier, R. CHAP is a newly identified Z-disc protein essential for heart and skeletal muscle function. J. Cell Sci. 2010, 123, 1141-1150. [CrossRef]

159. Van Eldik, W.; den Adel, B.; Monshouwer-Kloots, J.; Salvatori, D.; Maas, S.; van der Made, I.; Creemers, E.E.; Frank, D.; Frey, N.; Boontje, N.; et al. Z-disc protein CHAPb induces cardiomyopathy and contractile dysfunction in the postnatal heart. PLoS ONE 2017, 12, e0189139. [CrossRef]

160. Zou, J.; Tran, D.; Baalbaki, M.; Tang, L.F.; Poon, A.; Pelonero, A.; Titus, E.W.; Yuan, C.; Shi, C.; Patchava, S.; et al. An internal promoter underlies the difference in disease severity between $\mathrm{N}$ - and C-terminal truncation mutations of Titin in zebrafish. eLife 2015, 4, e09406. [CrossRef]

161. Moriarty, M.A.; Ryan, R.; Lalor, P.; Dockery, P.; Byrnes, L.; Grealy, M. Loss of plakophilin 2 disrupts heart development in zebrafish. Int. J. Dev. Biol. 2012, 56, 711-718. [CrossRef]

162. Giuliodori, A.; Beffagna, G.; Marchetto, G.; Fornetto, C.; Vanzi, F.; Toppo, S.; Facchinello, N.; Santimaria, M.; Vettori, A.; Rizzo, S.; et al. Loss of cardiac Wnt/ $\beta$-catenin signalling in desmoplakin-deficient AC8 zebrafish models is rescuable by genetic and pharmacological intervention. Cardiovasc. Res. 2018, 114, 1082-1097. [CrossRef]

163. Zhang, Y.; Shimizu, H.; Siu, K.L.; Mahajan, A.; Chen, J.N.; Cai, H. NADPH oxidase 4 induces cardiac arrhythmic phenotype in zebrafish. J. Biol. Chem. 2014, 289, 23200-23208. [CrossRef]

164. Kapplinger, J.D.; Tester, D.J.; Alders, M.; Benito, B.; Berthet, M.; Brugada, J.; Brugada, P.; Fressart, V.; Guerchicoff, A.; Harris-Kerr, C.; et al. An international compendium of mutations in the SCN5A-encoded cardiac sodium channel in patients referred for Brugada syndrome genetic testing. Heart Rhythm 2010, 7, 33-46. [CrossRef]

165. Watanabe, H.; Minamino, T. Genetics of Brugada syndrome. J. Hum. Genet. 2016, 61, 57-60. [CrossRef]

166. Watanabe, H.; Koopmann, T.T.; Le Scouarnec, S.; Yang, T.; Ingram, C.R.; Schott, J.J.; Demolombe, S.; Probst, V.; Anselme, F.; Escande, D.; et al. Sodium channel $\beta 1$ subunit mutations associated with Brugada syndrome and cardiac conduction disease in humans. J. Clin. Investig. 2008, 118, 2260-2268. [CrossRef]

167. Juang, J.J.; Binda, A.; Lee, S.J.; Hwang, J.J.; Chen, W.J.; Liu, Y.B.; Lin, L.Y.; Yu, C.C.; Ho, L.T.; Huang, H.C.; et al. GSTM3 variant is a novel genetic modifier in Brugada syndrome, a disease with risk of sudden cardiac death. EBioMedicine 2020, 57, 102843. [CrossRef]

168. Sander, P.; Feng, M.; Schweitzer, M.K.; Wilting, F.; Gutenthaler, S.M.; Arduino, D.M.; Fischbach, S.; Dreizehnter, L.; Moretti, A.; Gudermann, T.; et al. Approved drugs ezetimibe and disulfiram enhance mitochondrial $\mathrm{Ca}(2+)$ uptake and suppress cardiac arrhythmogenesis. Br. J. Pharmacol. 2021, 178, 4518-4532. [CrossRef]

169. Kleinhans, D.S.; Lecaudey, V. Standardized mounting method of (zebrafish) embryos using a 3D-printed stamp for high-content, semi-automated confocal imaging. BMC Biotechnol. 2019, 19, 68. [CrossRef]

170. Von der Heyde, B.; Emmanouilidou, A.; Mazzaferro, E.; Vicenzi, S.; Höijer, I.; Klingström, T.; Jumaa, S.; Dethlefsen, O.; Snieder, H.; de Geus, E.; et al. Translating GWAS-identified loci for cardiac rhythm and rate using an in vivo image- and CRISPR/Cas9-based approach. Sci. Rep. 2020, 10, 11831. [CrossRef]

171. De Luca, E.; Zaccaria, G.M.; Hadhoud, M.; Rizzo, G.; Ponzini, R.; Morbiducci, U.; Santoro, M.M. ZebraBeat: A flexible platform for the analysis of the cardiac rate in zebrafish embryos. Sci. Rep. 2014, 4, 4898. [CrossRef]

172. Sala, L.; Meer, B.J.V.; Tertoolen, L.G.J.; Bakkers, J.; Bellin, M.; Davis, R.P.; Denning, C.; Dieben, M.A.E.; Eschenhagen, T.; Giacomelli, E.; et al. MUSCLEMOTION. Circ. Res. 2018, 122, e5-e16. [CrossRef]

173. Farhan, A.; Kurnia, K.A.; Saputra, F.; Chen, K.H.-C.; Huang, J.-C.; Roldan, M.J.M.; Lai, Y.-H.; Hsiao, C.-D. An OpenCV-Based Approach for Automated Cardiac Rhythm Measurement in Zebrafish from Video Datasets. Biomolecules 2021, $11,1476$.

174. Power, R.M.; Huisken, J. A guide to light-sheet fluorescence microscopy for multiscale imaging. Nat. Methods 2017, 14, 360-373. [CrossRef] 
175. Sehnert, A.J.; Huq, A.; Weinstein, B.M.; Walker, C.; Fishman, M.; Stainier, D.Y. Cardiac troponin T is essential in sarcomere assembly and cardiac contractility. Nat. Genet. 2002, 31, 106-110. [CrossRef]

176. Taylor, J.M.; Nelson, C.J.; Bruton, F.A.; Kaveh, A.; Buckley, C.; Tucker, C.S.; Rossi, A.G.; Mullins, J.J.; Denvir, M.A. Adaptive prospective optical gating enables day-long 3D time-lapse imaging of the beating embryonic zebrafish heart. Nat. Commun. 2019, 10, 5173. [CrossRef]

177. Akerboom, J.; Chen, T.W.; Wardill, T.J.; Tian, L.; Marvin, J.S.; Mutlu, S.; Calderón, N.C.; Esposti, F.; Borghuis, B.G.; Sun, X.R.; et al. Optimization of a GCaMP calcium indicator for neural activity imaging. J. Neurosci. 2012, 32, 13819-13840. [CrossRef]

178. Salgado-Almario, J.; Vicente, M.; Vincent, P.; Domingo, B.; Llopis, J. Mapping Calcium Dynamics in the Heart of Zebrafish Embryos with Ratiometric Genetically Encoded Calcium Indicators. Int. J. Mol. Sci. 2020, 21, 6610. [CrossRef]

179. Vicente, M.; Salgado-Almario, J.; Collins, M.M.; Martínez-Sielva, A.; Minoshima, M.; Kikuchi, K.; Domingo, B.; Llopis, J. Cardioluminescence in Transgenic Zebrafish Larvae: A Calcium Imaging Tool to Study Drug Effects and Pathological Modeling. Biomedicines 2021, 9, 1294.

180. Tsutsui, H.; Higashijima, S.; Miyawaki, A.; Okamura, Y. Visualizing voltage dynamics in zebrafish heart. J. Physiol. 2010, 588, 2017-2021. [CrossRef]

181. Tsutsui, H.; Karasawa, S.; Okamura, Y.; Miyawaki, A. Improving membrane voltage measurements using FRET with new fluorescent proteins. Nat. Methods 2008, 5, 683-685. [CrossRef]

182. Hou, J.H.; Kralj, J.M.; Douglass, A.D.; Engert, F.; Cohen, A.E. Simultaneous mapping of membrane voltage and calcium in zebrafish heart in vivo reveals chamber-specific developmental transitions in ionic currents. Front. Physiol. 2014, 5, 344. [CrossRef]

183. Asimaki, A.; Kapoor, S.; Plovie, E.; Arndt, A.K.; Adams, E.; Liu, Z.; James, C.A.; Judge, D.P.; Calkins, H.; Churko, J.; et al. Identification of a New Modulator of the Intercalated Disc in a Zebrafish Model of Arrhythmogenic Cardiomyopathy. Sci. Transl. Med. 2014, 6, 240ra274. [CrossRef]

184. Zhang, P.-C.; Llach, A.; Sheng, X.Y.; Hove-Madsen, L.; Tibbits, G.F. Calcium handling in zebrafish ventricular myocytes. Am. J. Physiol.-Regul. Integr. Comp. Physiol. 2011, 300, R56-R66. [CrossRef]

185. Bensimon-Brito, A.; Boezio, G.L.M.; Cardeira-da-Silva, J.; Wietelmann, A.; Ramkumar, S.; Lundegaard, P.R.; Helker, C.S.M.; Ramadass, R.; Piesker, J.; Nauerth, A.; et al. Integration of multiple imaging platforms to uncover cardiovascular defects in adult zebrafish. Cardiovasc. Res. 2021, cvab310. [CrossRef]

186. Koth, J.; Maguire, M.L.; McClymont, D.; Diffley, L.; Thornton, V.L.; Beech, J.; Patient, R.K.; Riley, P.R.; Schneider, J.E. HighResolution Magnetic Resonance Imaging of the Regenerating Adult Zebrafish Heart. Sci. Rep. 2017, 7, 2917. [CrossRef]

187. Rosello, M.; Vougny, J.; Czarny, F.; Mione, M.C.; Concordet, J.P.; Albadri, S.; Del Bene, F. Precise base editing for the in vivo study of developmental signaling and human pathologies in zebrafish. eLife 2021, 10, e65552. [CrossRef]

188. Prykhozhij, S.V.; Fuller, C.; Steele, S.L.; Veinotte, C.J.; Razaghi, B.; Robitaille, J.M.; McMaster, C.R.; Shlien, A.; Malkin, D.; Berman, J.N. Optimized knock-in of point mutations in zebrafish using CRISPR/Cas9. Nucleic Acids Res. 2018, 46, e102. [CrossRef]

189. Burg, L.; Palmer, N.; Kikhi, K.; Miroshnik, E.S.; Rueckert, H.; Gaddy, E.; MacPherson Cunningham, C.; Mattonet, K.; Lai, S.L.; Marín-Juez, R.; et al. Conditional mutagenesis by oligonucleotide-mediated integration of loxP sites in zebrafish. PLoS Genet. 2018, 14, e1007754. [CrossRef]

190. Hoshijima, K.; Jurynec, M.J.; Grunwald, D.J. Precise Editing of the Zebrafish Genome Made Simple and Efficient. Dev. Cell 2016, 36, 654-667. [CrossRef]

191. MacRae, C.A. Cardiac arrhythmia: In vivo screening in the zebrafish to overcome complexity in drug discovery. Expert Opin. Drug Discov. 2010, 5, 619-632. [CrossRef] 